Supporting Information

\title{
Synthesis and Evaluation of 1-Deoxy-D-xylulose 5-Phosphate Analogues as Chelation Based Inhibitors of Methylerythritol Phosphate Synthase
}

\author{
Joel R. Walker and C. Dale Poulter* \\ 315 South 1400 East RM 2020; Department of Chemistry; University of Utah, Salt Lake \\ City, UT, USA 84112 \\ poulter@chemistry.utah.edu
}

Table of Contents

General Methods

S2

Experimental Procedures

S3-S7

MEP Synthase Inhibition Assays

S7

${ }^{1} \mathrm{H}$ and ${ }^{13} \mathrm{C}$ NMR spectra for $\mathbf{1 0}$

S8-S9

${ }^{1} \mathrm{H},{ }^{13} \mathrm{C}$, and ${ }^{31} \mathrm{P}$ NMR spectra for $\mathbf{1}$

S10-S12

${ }^{1} \mathrm{H},{ }^{13} \mathrm{C}$, and ${ }^{31} \mathrm{P}$ NMR spectra for 3

S13-S15

${ }^{1} \mathrm{H}$ and ${ }^{13} \mathrm{C}$ NMR spectra for $\mathbf{1 1}$

S16-S17

${ }^{1} \mathrm{H},{ }^{13} \mathrm{C}$, and ${ }^{31} \mathrm{P}$ NMR spectra for 2

S18-S20

${ }^{1} \mathrm{H}$ and ${ }^{13} \mathrm{C}$ NMR spectra for $\mathbf{1 2}$

$\mathrm{S} 21-\mathrm{S} 22$

${ }^{1} \mathrm{H},{ }^{13} \mathrm{C}$, and ${ }^{31} \mathrm{P}$ NMR spectra for 4

$\mathrm{S} 23-\mathrm{S} 25$

${ }^{1} \mathrm{H}$ and ${ }^{13} \mathrm{C}$ NMR spectra for $\mathbf{1 3}$

S26-S27

${ }^{1} \mathrm{H},{ }^{13} \mathrm{C}$, and ${ }^{31} \mathrm{P}$ NMR spectra for 5

S28-S30

${ }^{1} \mathrm{H}$ and ${ }^{13} \mathrm{C}$ NMR spectra for $\mathbf{1 6}$

S31-S32

${ }^{1} \mathrm{H}$ and ${ }^{13} \mathrm{C}$ NMR spectra for $\mathbf{1 7}$

S33-S34

${ }^{1} \mathrm{H}$ and ${ }^{13} \mathrm{C}$ NMR spectra for $\mathbf{1 8}$

S35-S36

${ }^{1} \mathrm{H}$ and ${ }^{13} \mathrm{C}$ NMR spectra for $\mathbf{1 9}$

S37-S38

${ }^{1} \mathrm{H},{ }^{13} \mathrm{C}$, and ${ }^{31} \mathrm{P}$ NMR spectra for 6

S39-S41 


\section{General Methods}

Anhydrous solvents were obtained using a standard solvent purification system. TLC was performed on silica gel $0.25 \mathrm{~mm}$ aluminum plates. Silica gel column chromatography was performed with silica gel 60, 230-400 mesh. Cellulose chromatography was performed on CF-11 fibrous cellulose, and cellulose TLC was performed on cellulose F $0.1 \mathrm{~mm}$ plastic sheets. Cellulose TLC plates were visualized by sulfosalicylic acid-ferric chloride stain. Melting points were determined using a capillary apparatus and are uncorrected. Optical rotations were conducted at $25^{\circ} \mathrm{C}$ and reported in g/100 mL. NMR spectra were recorded at $300 \mathrm{MHz}\left({ }^{1} \mathrm{H}\right.$ NMR), $75 \mathrm{MHz}\left({ }^{13} \mathrm{C} \mathrm{NMR}\right)$, or $121 \mathrm{MHz}\left({ }^{31} \mathrm{P}\right.$ NMR). ${ }^{1} \mathrm{H}$ NMR spectra were referenced to residual protons in $\mathrm{CDCl}_{3}(\delta$ $7.27 \mathrm{ppm}), \mathrm{DMK}-\mathrm{d}_{6}(\delta 2.05 \mathrm{ppm})$, or $\mathrm{D}_{2} \mathrm{O}(\delta 4.80 \mathrm{ppm}) .{ }^{13} \mathrm{C}$ NMR spectra were referenced to $\mathrm{CDCl}_{3}(\delta 77.00 \mathrm{ppm}), \mathrm{DMK}-\mathrm{d}_{6}(\delta 29.92 \mathrm{ppm})$, or external $\mathrm{MeOH}(\delta 49.0$

$\mathrm{ppm})$ in $\mathrm{D}_{2} \mathrm{O} .{ }^{31} \mathrm{P}$ NMR spectra were referenced to external phosphoric acid $(\delta 0.00 \mathrm{ppm})$ in $\mathrm{D}_{2} \mathrm{O}$. 


\section{Experimental Procedures}

\section{(2S,3R)-Methyl 5-hydroxymethyl-2,2-dimethyl-[1,3]dioxolane-4-carboxylate (8)}

(-)-Dimethyl 2,3-O-isopropylidene-D-tartrate (7) (7.6 g, $34.8 \mathrm{mmol})$ in distilled methanol $(150 \mathrm{~mL})$ was cooled to $0{ }^{\circ} \mathrm{C}$ before $\mathrm{NaBH}_{4}(790 \mathrm{mg}, 20.9 \mathrm{mmol})$ was added slowly in aliquots. After $30 \mathrm{~min}$ at $0{ }^{\circ} \mathrm{C}$ the solution was concentrated, diluted with ethyl acetate, and washed with water and brine. The aqueous layers were extracted with ethyl acetate, and the combined organic layers were dried $\left(\mathrm{MgSO}_{4}\right)$ and concentrated. The residue was chromatographed (1:1 hexanes/ethyl acetate) to give $2.13 \mathrm{~g}$ (32\%) of oil, along with recovered starting material. The ${ }^{1} \mathrm{H}$ NMR spectrum matched that previously reported. $^{15}$

\section{(2S,3R)-Methyl 5-(Bis-benzyloxyphosphoryloxymethyl)-2,2-dimethyl-[1,3]dioxolane-}

\section{4-carboxylate (9)}

A solution of tribenzyl phosphate $(4.30 \mathrm{~g}, 12.2 \mathrm{mmol})$ in $\mathrm{CH}_{2} \mathrm{Cl}_{2}(100 \mathrm{~mL})$ was cooled to $-30{ }^{\circ} \mathrm{C}$ before iodine $(3.00 \mathrm{~g}, 11.8 \mathrm{mmol})$ was added and allowed to fully dissolve. The clear, colorless solution of dibenzyl phosphoroiodidate was cannulated into a solution of $8(0.75 \mathrm{~g}, 3.9 \mathrm{mmol})$ and pyridine $(1.3 \mathrm{~mL}, 15.8 \mathrm{mmol})$ in $\mathrm{CH}_{2} \mathrm{Cl}_{2}(50 \mathrm{~mL})$. After $2 \mathrm{~h}$ at $-30^{\circ} \mathrm{C}$ and $2 \mathrm{~h}$ at $\mathrm{rt}$, the mixture was filtered, concentrated, and redissolved in ether. The organic layer was washed with $0.3 \mathrm{M} \mathrm{KHSO}_{4}$, saturated $\mathrm{NaHCO}_{3}$, and brine. The aqueous layers were extracted with ether, and the combined organic layers were dried $\left(\mathrm{MgSO}_{4}\right)$ and concentrated. The residue was chromatographed (1:1 hexanes/ethyl 
acetate) to give $1.40 \mathrm{~g}(79 \%)$ of clear oil. The ${ }^{1} \mathrm{H}$ NMR spectrum matched that previously reported. ${ }^{17}$

\section{(2S,3R)-2,3-Dihydroxy-3-hydroxycarbamoylpropyl phosphate (2)}

To a solution of $\mathbf{1 1}(86 \mathrm{mg}, 0.19 \mathrm{mmol})$ in methanol $(20 \mathrm{~mL})$ was added $10 \%$ $\mathrm{Pd} / \mathrm{C}(10 \mathrm{mg})$. After $2 \mathrm{~h}$ under hydrogen $(1 \mathrm{~atm})$ the suspension was filtered. The filtrate was concentrated and dissolved in water. The mixture was allowed to stir for 3 days at rt. Lyophilization, followed by cellulose chromatography (7:3 isopropanol/water, $50 \mathrm{mM}$ $\left.\mathrm{NH}_{4} \mathrm{HCO}_{3}\right)$, gave $24 \mathrm{mg}(43 \%)$ of a white foam. $[\alpha]_{\mathrm{D}}-32.64\left(c\right.$ 1.2, $\left.\mathrm{H}_{2} \mathrm{O}\right) ;{ }^{1} \mathrm{H}$ NMR $\left(\mathrm{D}_{2} \mathrm{O}\right) \delta 3.82-3.95(\mathrm{~m}, 2 \mathrm{H}), 4.13(\mathrm{td}, 1 \mathrm{H}, J=2.4,6.3 \mathrm{~Hz}), 4.28(\mathrm{~d}$, rotamer, $J=2.4 \mathrm{~Hz})$, $4.34(\mathrm{~d}, 1 \mathrm{H}, J=2.4 \mathrm{~Hz}) ;{ }^{13} \mathrm{C}$ NMR $\left(\mathrm{D}_{2} \mathrm{O}\right) \delta 64.7(\mathrm{~d}, J=5.0 \mathrm{~Hz}), 70.5,70.7(\mathrm{~d}, J=8.0$ $\mathrm{Hz}), 171.0 ;{ }^{31} \mathrm{P}$ NMR $\left(\mathrm{D}_{2} \mathrm{O}\right) \delta 1.21 ; \mathrm{HRMS}(\mathrm{FAB})$ calcd for $\mathrm{C}_{4} \mathrm{H}_{10} \mathrm{NO}_{8} \mathrm{P}(\mathrm{M}-\mathrm{H})$ 230.0066 , found 230.0063 .

\section{(2S,3R)-3-Carbamoyl-2,3-dihydroxypropyl phosphate (4)}

To a solution of $\mathbf{1 2}(193 \mathrm{mg}, 0.44 \mathrm{mmol})$ in methanol $(50 \mathrm{~mL})$ was added $10 \%$ $\mathrm{Pd} / \mathrm{C}(20 \mathrm{mg})$. After $3 \mathrm{~h}$ under hydrogen $(1 \mathrm{~atm})$ the suspension was filtered. The filtrate was concentrated and dissolved in water. The mixture was allowed to stir for 5 days at rt. Lyophilization, followed by cellulose chromatography (7:3 isopropanol/water, $50 \mathrm{mM}$ $\mathrm{NH}_{4} \mathrm{HCO}_{3}$ ), gave $100 \mathrm{mg}$ (quant) of a white foam. [ $\left.\alpha\right]_{\mathrm{D}}-33.34\left(\right.$ c 2.3, $\left.\mathrm{H}_{2} \mathrm{O}\right) ;{ }^{1} \mathrm{H} \mathrm{NMR}$ $\left(\mathrm{D}_{2} \mathrm{O}\right) \delta 3.83(\mathrm{t}, 2 \mathrm{H}, J=6.6 \mathrm{~Hz}), 4.12(\mathrm{td}, 1 \mathrm{H}, J=2.1,6.6 \mathrm{~Hz}), 4.30(\mathrm{~d}, 1 \mathrm{H}, J=2.1 \mathrm{~Hz})$;

${ }^{13} \mathrm{C}$ NMR $\left(\mathrm{D}_{2} \mathrm{O}\right) \delta 64.4(\mathrm{~d}, J=4.5 \mathrm{~Hz}), 71.0,71.0,178.1 ;{ }^{31} \mathrm{P}$ NMR $\left(\mathrm{D}_{2} \mathrm{O}\right) \delta 1.14 ; \mathrm{HRMS}$ (FAB) calcd for $\mathrm{C}_{4} \mathrm{H}_{10} \mathrm{O}_{7} \mathrm{P}(\mathrm{M}-\mathrm{H})$ 214.0117, found 214.0120. 


\section{$(2 R, 3 R)-2,3,4-T r i h y d r o x y-b u t y l$ phosphate (5)}

To a solution of 13 (50 mg, $0.12 \mathrm{mmol})$ in methanol (10 mL) was added $10 \%$ $\mathrm{Pd} / \mathrm{C}(5 \mathrm{mg})$. After $2 \mathrm{~h}$ under hydrogen $(1 \mathrm{~atm})$ the suspension was filtered. The filtrate was concentrated and dissolved in water. The mixture was allowed to stir for 3 days at rt. Lyophilization gave $23 \mathrm{mg}(94 \%)$ of glassy foam. $[\alpha]_{\mathrm{D}}-0.85\left(c 2.0, \mathrm{H}_{2} \mathrm{O}\right) ;{ }^{1} \mathrm{H}$ NMR $\left(\mathrm{D}_{2} \mathrm{O}\right) \delta 3.56-4.01(\mathrm{~m}, 6 \mathrm{H}) ;{ }^{13} \mathrm{C} \mathrm{NMR}\left(\mathrm{D}_{2} \mathrm{O}\right) \delta 62.6,66.9(\mathrm{~d}, J=5.0 \mathrm{~Hz}), 70.2(\mathrm{~d}, J=8.0$ $\mathrm{Hz}), 71.3 ;{ }^{31} \mathrm{P}$ NMR $\left(\mathrm{D}_{2} \mathrm{O}\right) \delta$ 1.30; HRMS (FAB) calcd for $\mathrm{C}_{4} \mathrm{H}_{11} \mathrm{O}_{7} \mathrm{P}(\mathrm{M}-\mathrm{H})$ 201.0164, found 201.0141 .

\section{(4R,5R)-(2,2-Dimethyl-5-triisopropylsilanyloxymethyl-[1,3]dioxolan-4-yl)methanol} (15)

A suspension of $60 \%$ sodium hydride $(0.78 \mathrm{~g}, 19.5 \mathrm{mmol})$ in THF $(100 \mathrm{~mL})$ was cooled to $0{ }^{\circ} \mathrm{C}$ before $\mathbf{1 4}(2.88 \mathrm{~g}, 17.8 \mathrm{mmol})$ was added via cannula in $\mathrm{THF}(10 \mathrm{~mL})$. After warming to $\mathrm{rt}$ for $1 \mathrm{~h}$, the suspension was re-cooled to $0{ }^{\circ} \mathrm{C}$ and a solution of TIPSCl (3.8 mL, $17.8 \mathrm{mmol})$ in THF $(10 \mathrm{~mL})$ was added via cannula. After $3 \mathrm{~h}$ at $\mathrm{rt}$ the solution was diluted with ether and washed with water and brine. The aqueous layer was extracted with ether, and the combined organic layers were dried $\left(\mathrm{MgSO}_{4}\right)$ and concentrated. The residue was chromatographed (8:2 hexanes/ethyl acetate) to give 5.33 g $(94 \%)$ of an oil. The ${ }^{1} \mathrm{H}$ NMR matched that for previously reported material. ${ }^{18}$ 
tert-Butyl-\{(4R,5R)-5-(bis-benzyloxy-phosphoryloxymethyl)-2,2-dimethyl-

\section{$[1,3]$ dioxolan-4-ylmethyl\}carbamate (19)}

A solution of tribenzyl phosphate $(9.27 \mathrm{~g}, 26.3 \mathrm{mmol})$ in $\mathrm{CH}_{2} \mathrm{Cl}_{2}(100 \mathrm{~mL})$ was cooled to $-30{ }^{\circ} \mathrm{C}$ before iodine $(6.46 \mathrm{~g}, 25.5 \mathrm{mmol})$ was added and allowed to fully dissolve. The clear, colorless solution of dibenzyl phosphoroiodidate was cannulated into a solution of $18(2.21 \mathrm{~g}, 8.5 \mathrm{mmol})$ and pyridine $(2.75 \mathrm{~mL}, 15.8 \mathrm{mmol})$ in $\mathrm{CH}_{2} \mathrm{Cl}_{2}(50$ $\mathrm{mL}$ ). After $2 \mathrm{~h}$ at $-30^{\circ} \mathrm{C}$ and $2 \mathrm{~h}$ at $\mathrm{rt}$, the mixture was filtered, concentrated, and redissolved in ether. The organic layer was washed with $0.3 \mathrm{M} \mathrm{KHSO}_{4}$, saturated $\mathrm{NaHCO}_{3}$, and brine. The aqueous layers were extracted with ether, and the combined organic layers were dried $\left(\mathrm{MgSO}_{4}\right)$ and concentrated. The residue was chromatographed (1:1 hexanes/ethyl acetate) to give $3.61 \mathrm{~g}(81 \%)$ of clear oil. $[\alpha]_{\mathrm{D}}+5.88(c 5.6$, acetone $)$;

${ }^{1} \mathrm{H}$ NMR (acetone-d $\left.{ }_{6}\right) \delta 1.32(\mathrm{~s}, 3 \mathrm{H}), 1.34(\mathrm{~s}, 3 \mathrm{H}), 1.40(\mathrm{~s}, 9 \mathrm{H}), 3.28-3.36(\mathrm{~m}, 2 \mathrm{H}), 3.96-$ $4.18(\mathrm{~m}, 4 \mathrm{H}), 5.09(\mathrm{~d}, 2 \mathrm{H}, J=1.8 \mathrm{~Hz}), 5.12(\mathrm{~d}, 1 \mathrm{H}, J=1.8 \mathrm{~Hz}), 6.14(\mathrm{br} \mathrm{s}, 1 \mathrm{H}), 7.34-7.54$ $(\mathrm{m}, 10 \mathrm{H}) ;{ }^{13} \mathrm{C}$ NMR (acetone-d $\left.\mathrm{d}_{6}\right) \delta 27.3,27.6,28.7,43.0,67.8(\mathrm{~d}, J=5.2 \mathrm{~Hz}), 69.8,77.4$, $78.3(\mathrm{~d}, J=8.3 \mathrm{~Hz}), 79.1,110.00,128.9,129.3,129.4,137.4(\mathrm{~d}, J=7.5 \mathrm{~Hz}), 157.0$, $206.3 ;{ }^{31} \mathrm{P}$ NMR (acetone-d 6 ) $\delta$ 0.87; HRMS (CI) calcd for $\mathrm{C}_{26} \mathrm{H}_{36} \mathrm{NO}_{8} \mathrm{P}(\mathrm{M}+\mathrm{H})$ 522.2257 , found 522.2279.

\section{(2R,3R)-4-Amino-2,3-dihydroxybutyl phosphate (6)}

To a solution of $19(3.22 \mathrm{~g}, 6.2 \mathrm{mmol})$ in methanol $(50 \mathrm{~mL})$ was added $10 \% \mathrm{Pd} / \mathrm{C}$ (500 mg). After $4 \mathrm{~h}$ under hydrogen $(1 \mathrm{~atm})$ the suspension was filtered. The filtrate was concentrated and dissolved in $1 \mathrm{M} \mathrm{HCl}$. The mixture was allowed to stir for $24 \mathrm{~h}$ at $\mathrm{rt}$. Lyophilization, followed by cellulose chromatography (7:3 isopropanol/water, $50 \mathrm{mM}$ 
$\left.\mathrm{NH}_{4} \mathrm{HCO}_{3}\right)$, gave $510 \mathrm{mg}(52 \%)$ of a white foam. $[\alpha]_{\mathrm{D}}-3.38\left(c 2.3, \mathrm{H}_{2} \mathrm{O}\right) ;{ }^{1} \mathrm{H}$ NMR $\left(\mathrm{D}_{2} \mathrm{O}\right)$ 8 3.06-3.22 (m, 2H), 3.72-3.84 (m, 3H), 3.98-4.04 (m, $\left.1 \mathrm{H}\right) ;{ }^{13} \mathrm{C}$ NMR $\left(\mathrm{D}_{2} \mathrm{O}\right)$ $\delta$ 42.9, $65.3(\mathrm{~d}, J=4.5 \mathrm{~Hz}), 68.3,72.1(\mathrm{~d}, J=7.0 \mathrm{~Hz}) ;{ }^{31} \mathrm{P} \mathrm{NMR}\left(\mathrm{D}_{2} \mathrm{O}\right) \delta 5.00 ;$ HRMS (FAB) calcd for $\mathrm{C}_{4} \mathrm{H}_{12} \mathrm{NO}_{6} \mathrm{P}(\mathrm{M}+\mathrm{H})$ 202.0481, found 202.0478.

\section{MEP Synthase Inhibition Assays ${ }^{13,17,19}$}

Briefly, E. coli MEP synthase was obtained recombinantly by transforming $E$. coli BL21 cells using the plasmid pATK-III-146HB1, which encoded for the His 6 -tagged protein. The cells were harvested and the protein was isolated with Ni-NTA agarose using standard protocols. Enzyme concentration was obtained by measuring UV absorbance $\left(\varepsilon_{280}=25,710 \mathrm{M}^{-1} \mathrm{~cm}^{-1}\right)$ as calculated by Vector NTI for monomeric MEP synthase. The enzymatic conversion of DXP to MEP can be followed measuring the decrease in absorbance at $340 \mathrm{~nm}$, which is the oxidation of NADPH. DXP was synthesized by previously published methods. ${ }^{18}$ The concentrations of DXP and analogs 1-6 were determined by weight and confirmed by NMR. Standard $\mathrm{IC}_{50}$ assays were performed at $37^{\circ} \mathrm{C}$ in a total volume of $100 \mu \mathrm{L}$ containing $50 \mathrm{mM}$ HEPES (pH 7.6), 3 $\mathrm{mM} \mathrm{MgCl} 2,1 \mathrm{mg} / \mathrm{mL}$ BSA, $8 \mathrm{nM}$ MEP synthase, $100 \mu \mathrm{M} \mathrm{DXP}$, and varying amounts of analogs 1-6. The analogs were pre-incubated with the enzyme at $37{ }^{\circ} \mathrm{C}$ for $2 \mathrm{~min}$ and the reaction was initiated with the addition of substrate. Conversions were under $10 \%$ and the data was fitted using graphing software to obtain $\mathrm{IC}_{50}$ values. 


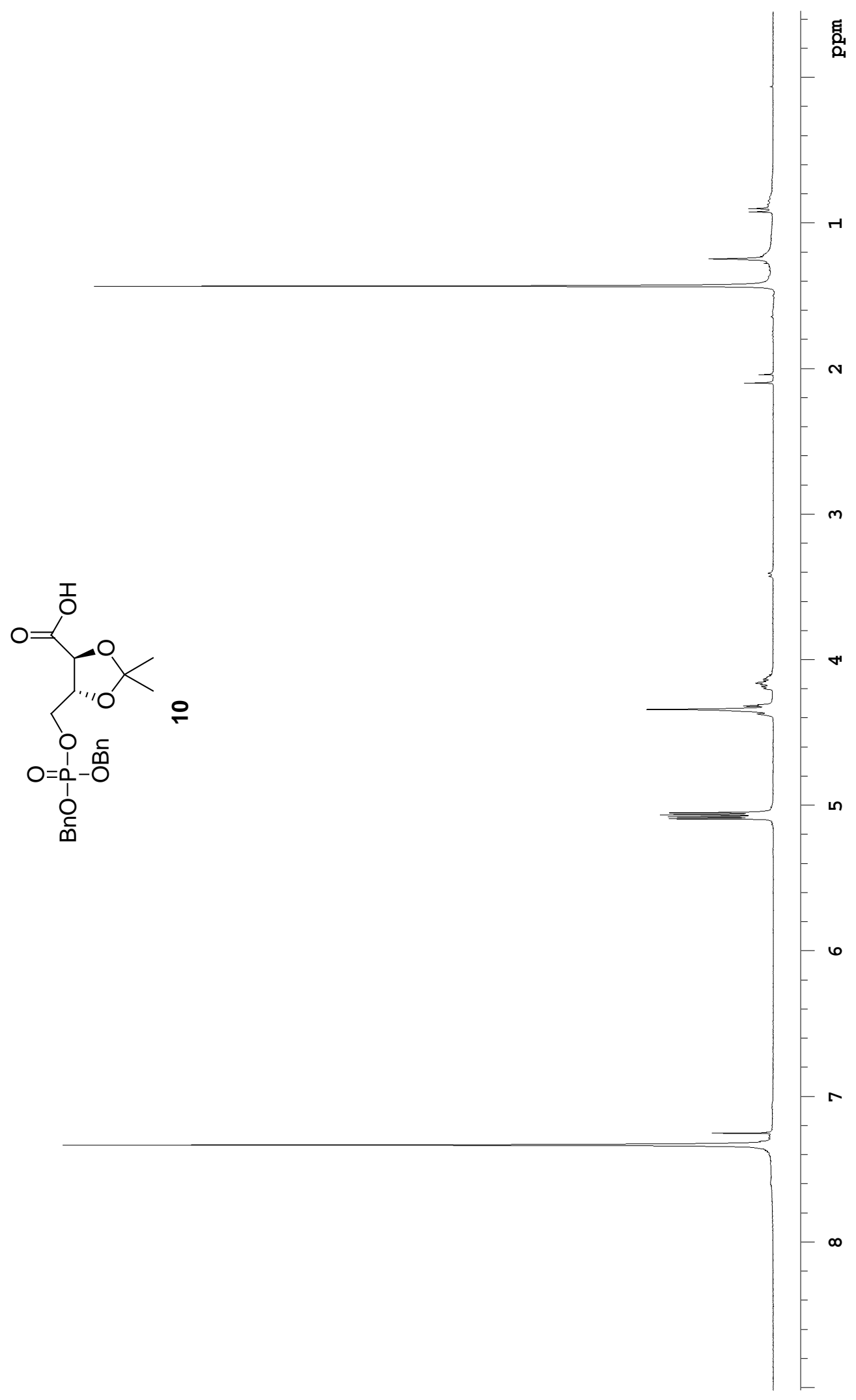




$$
1
$$




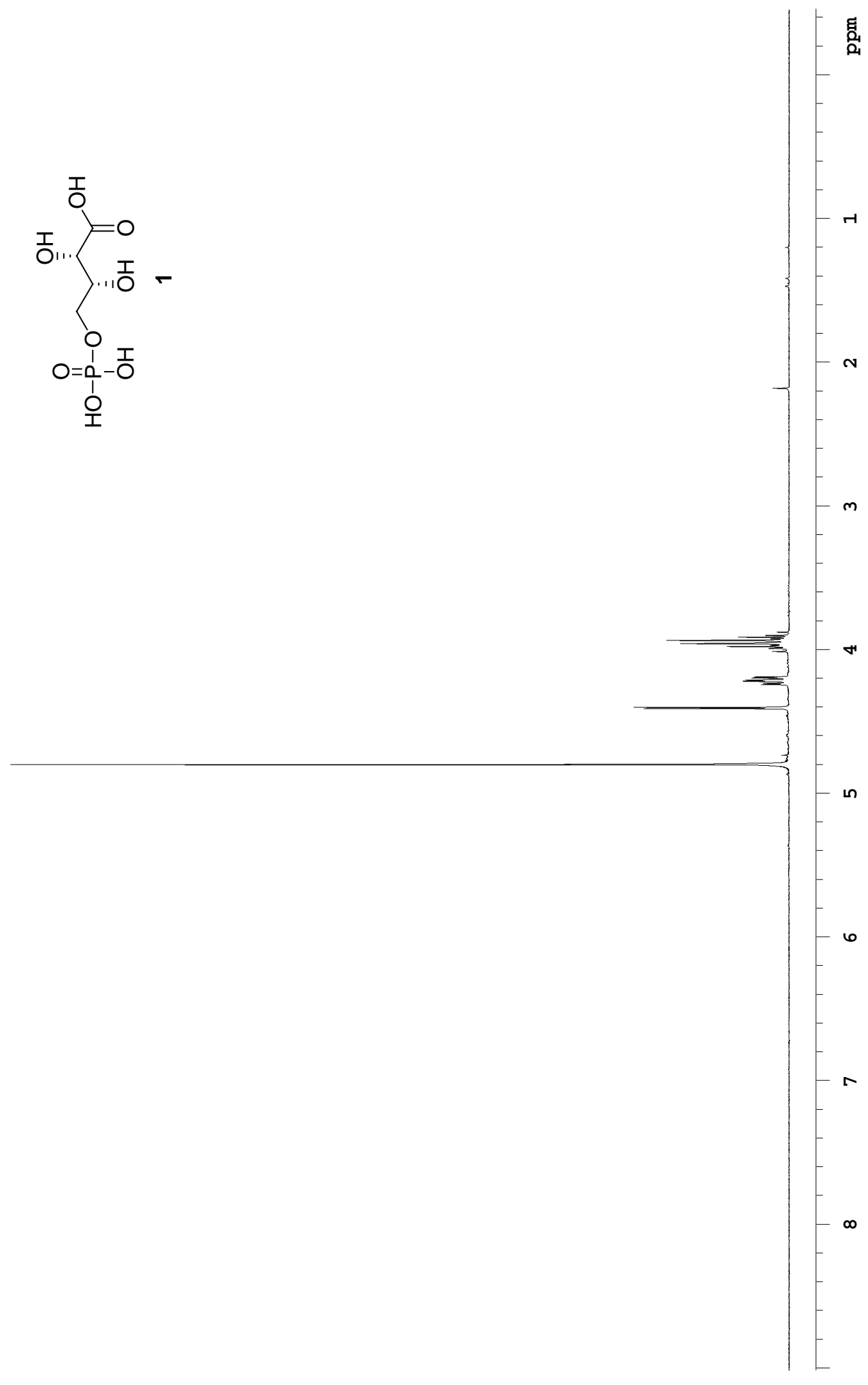



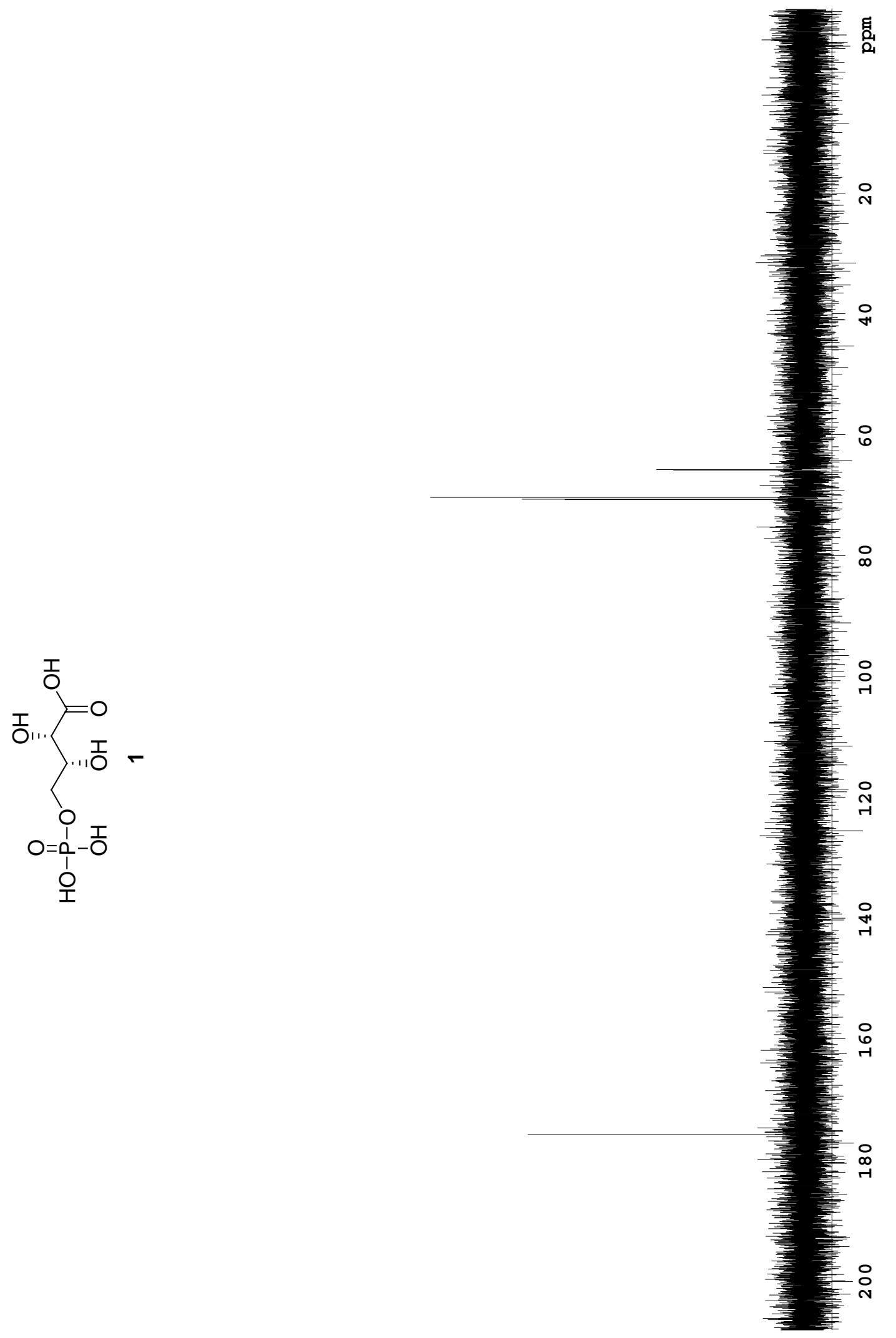

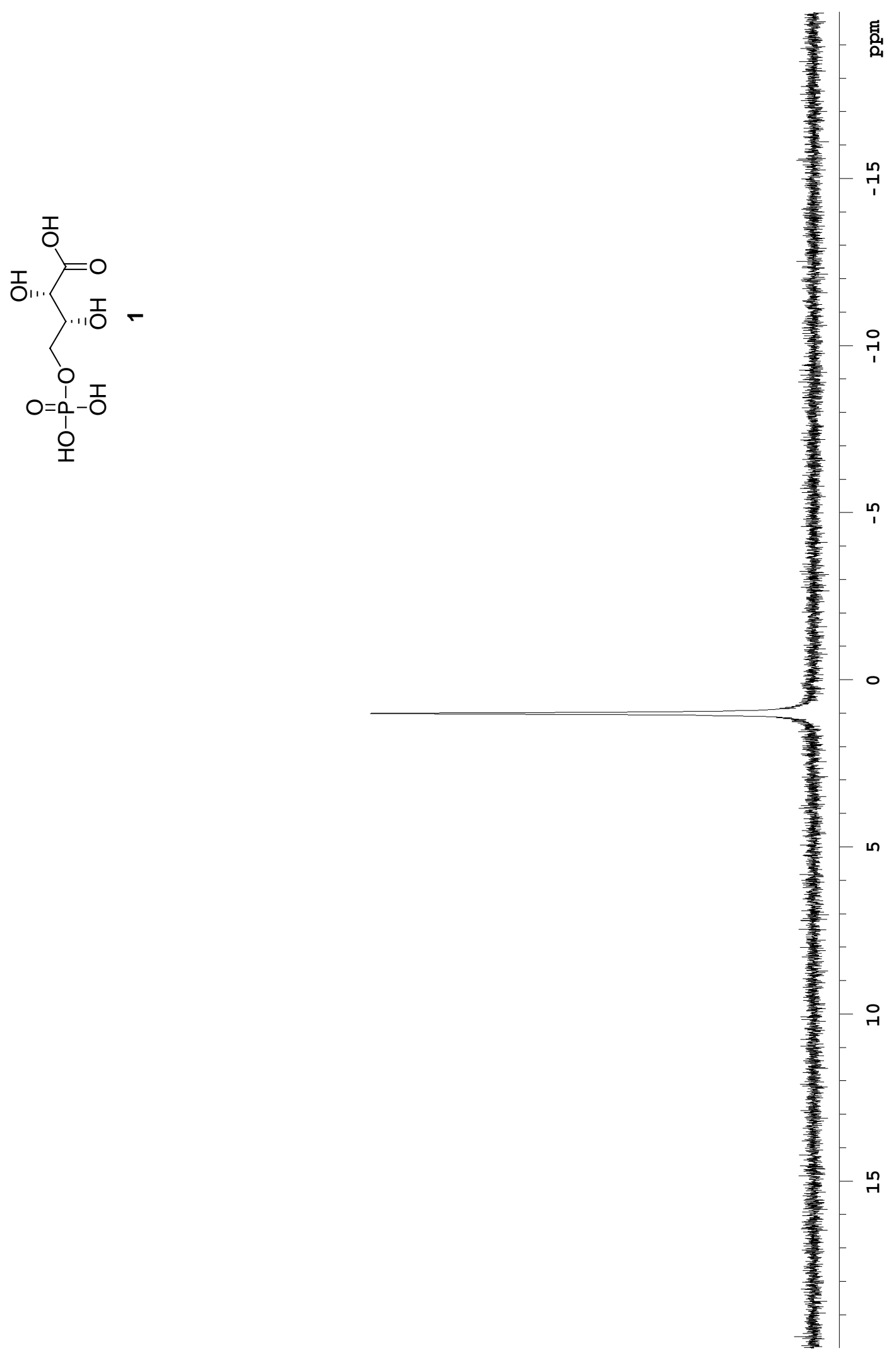


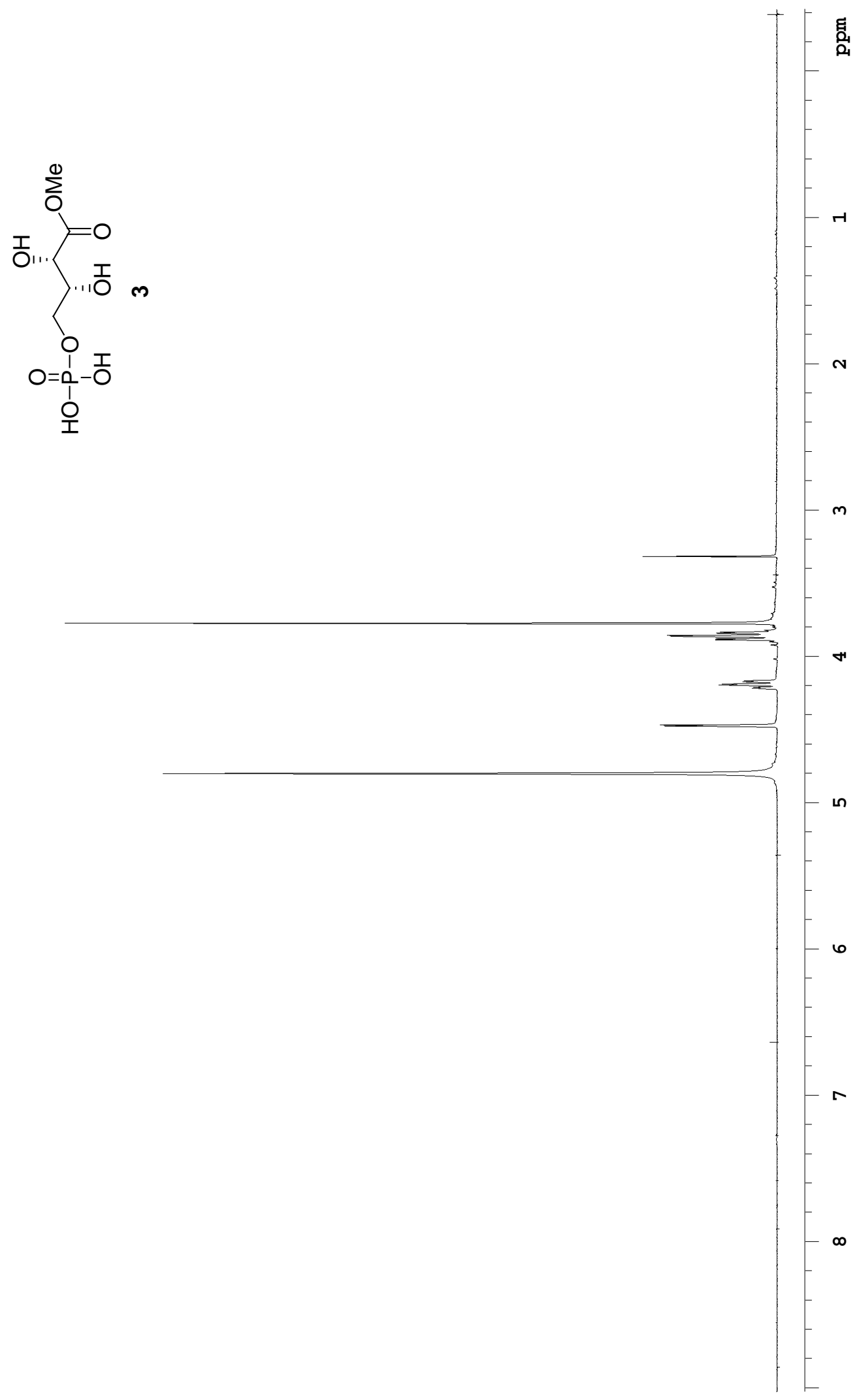



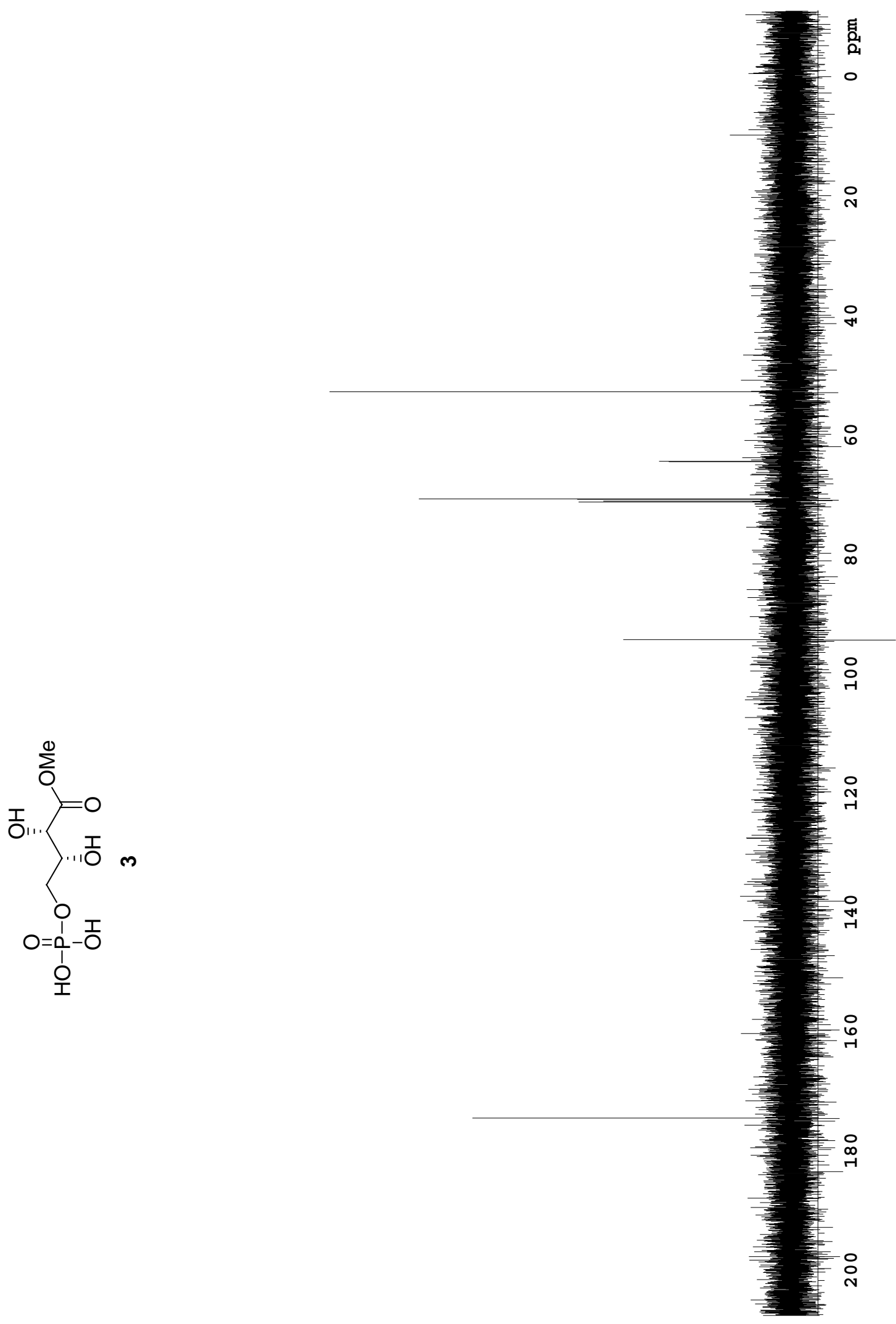

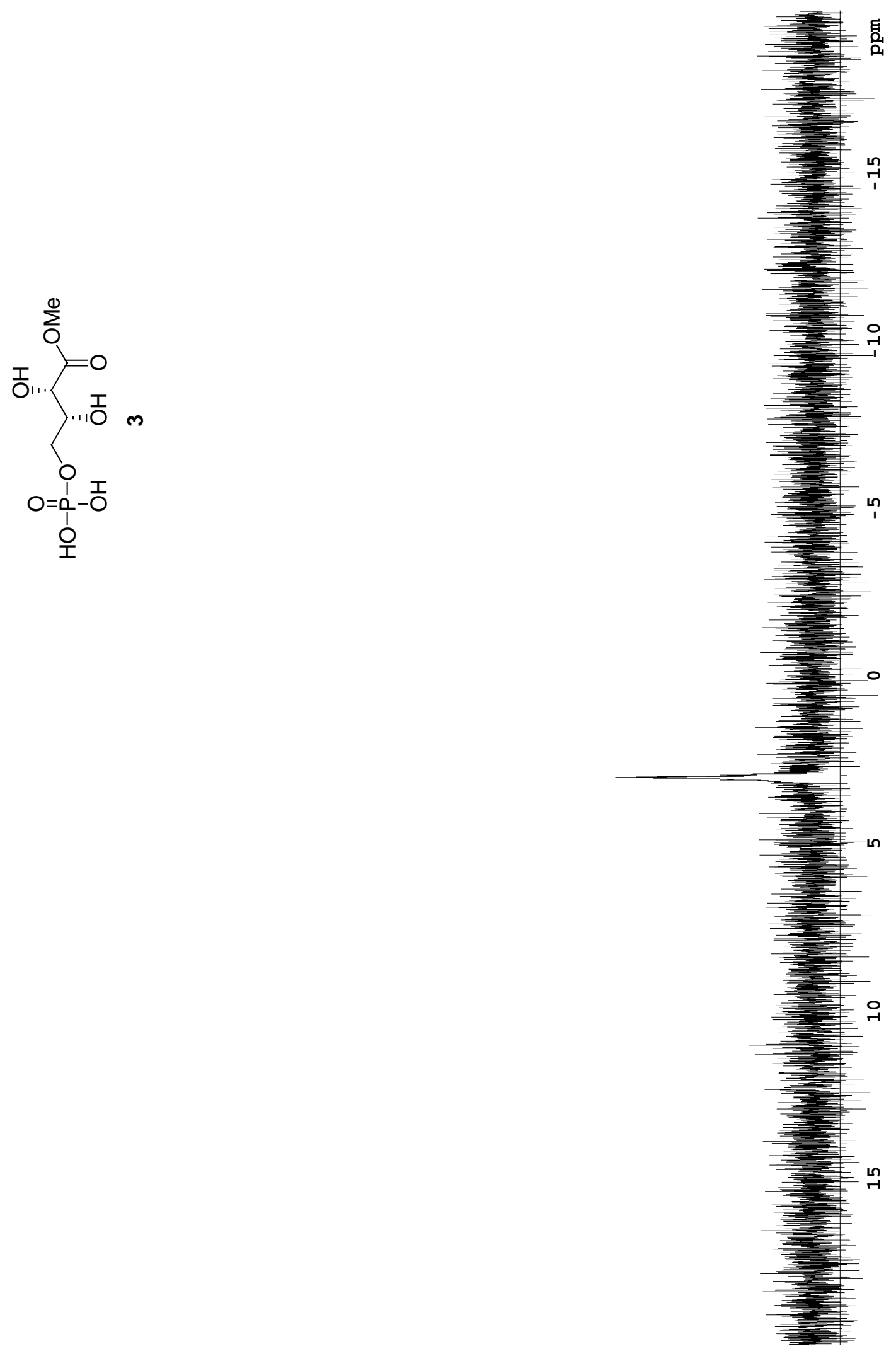


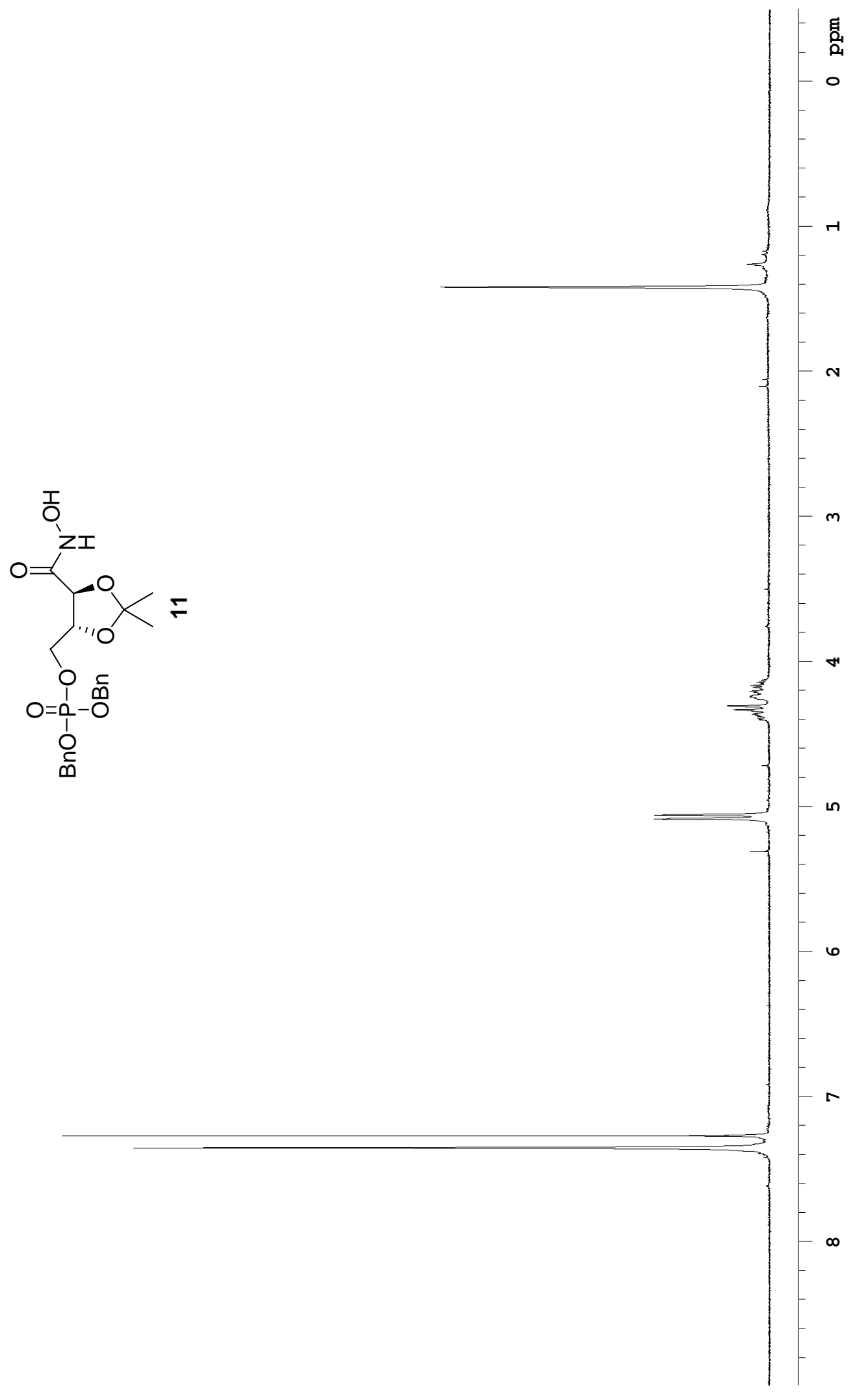



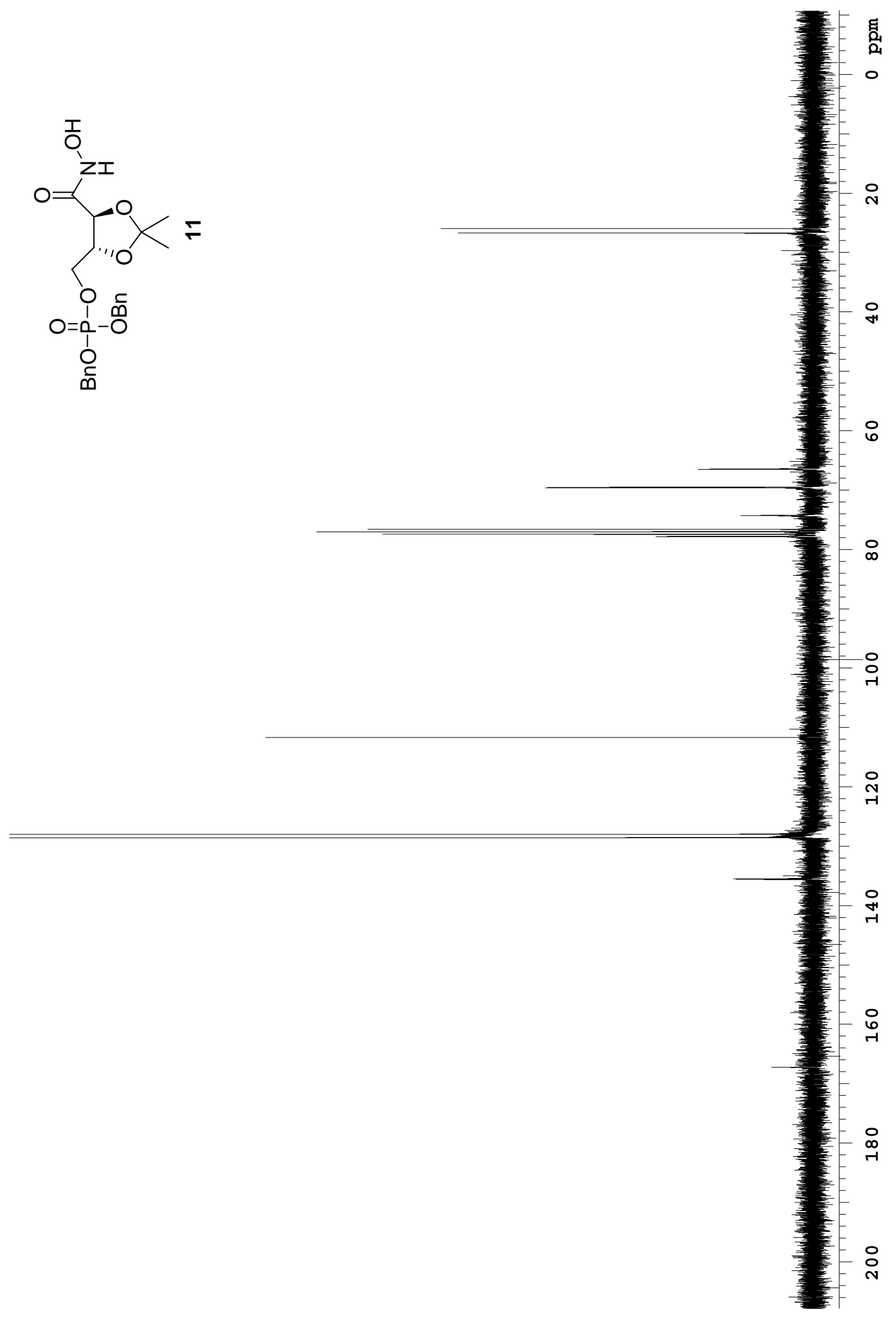


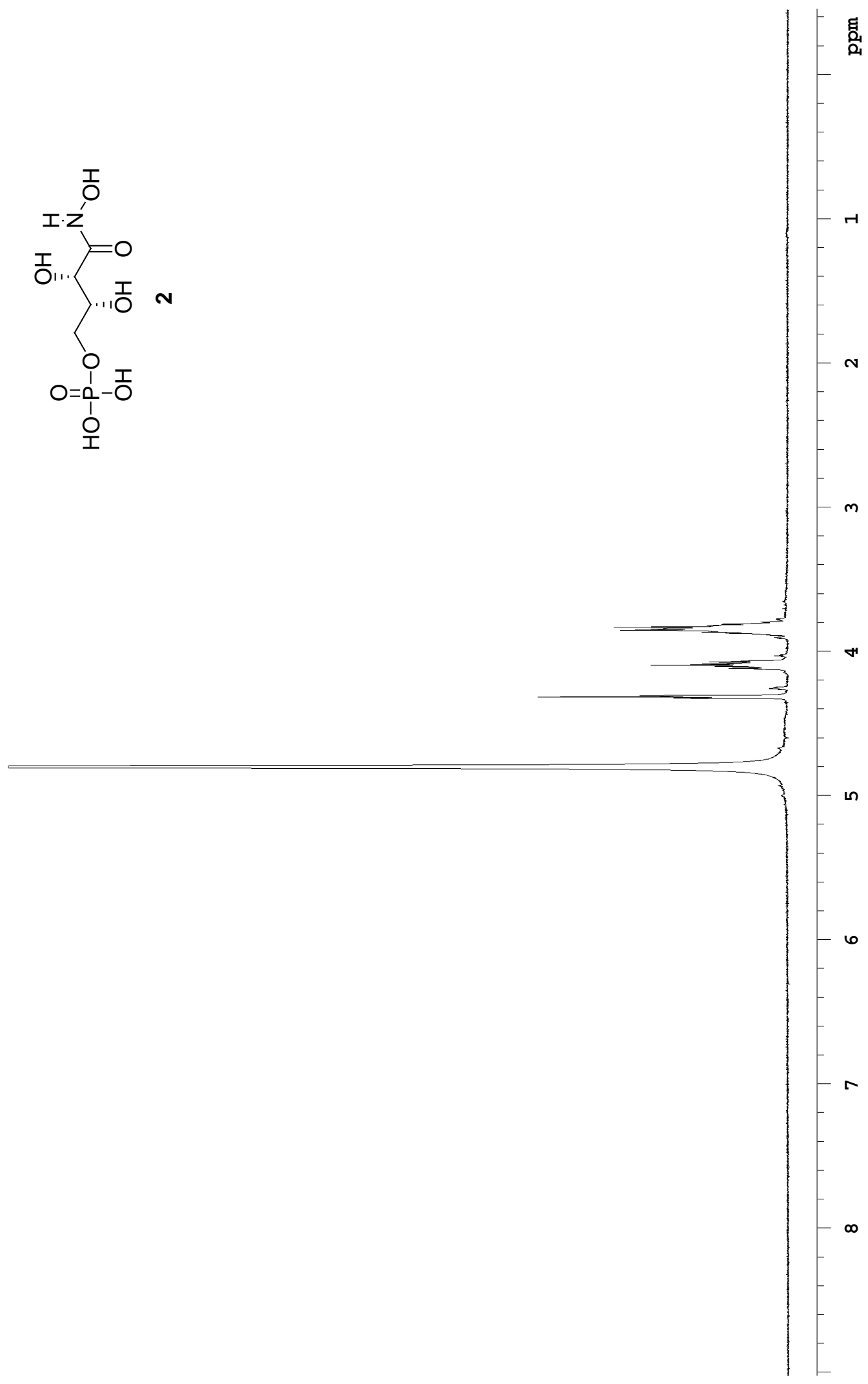



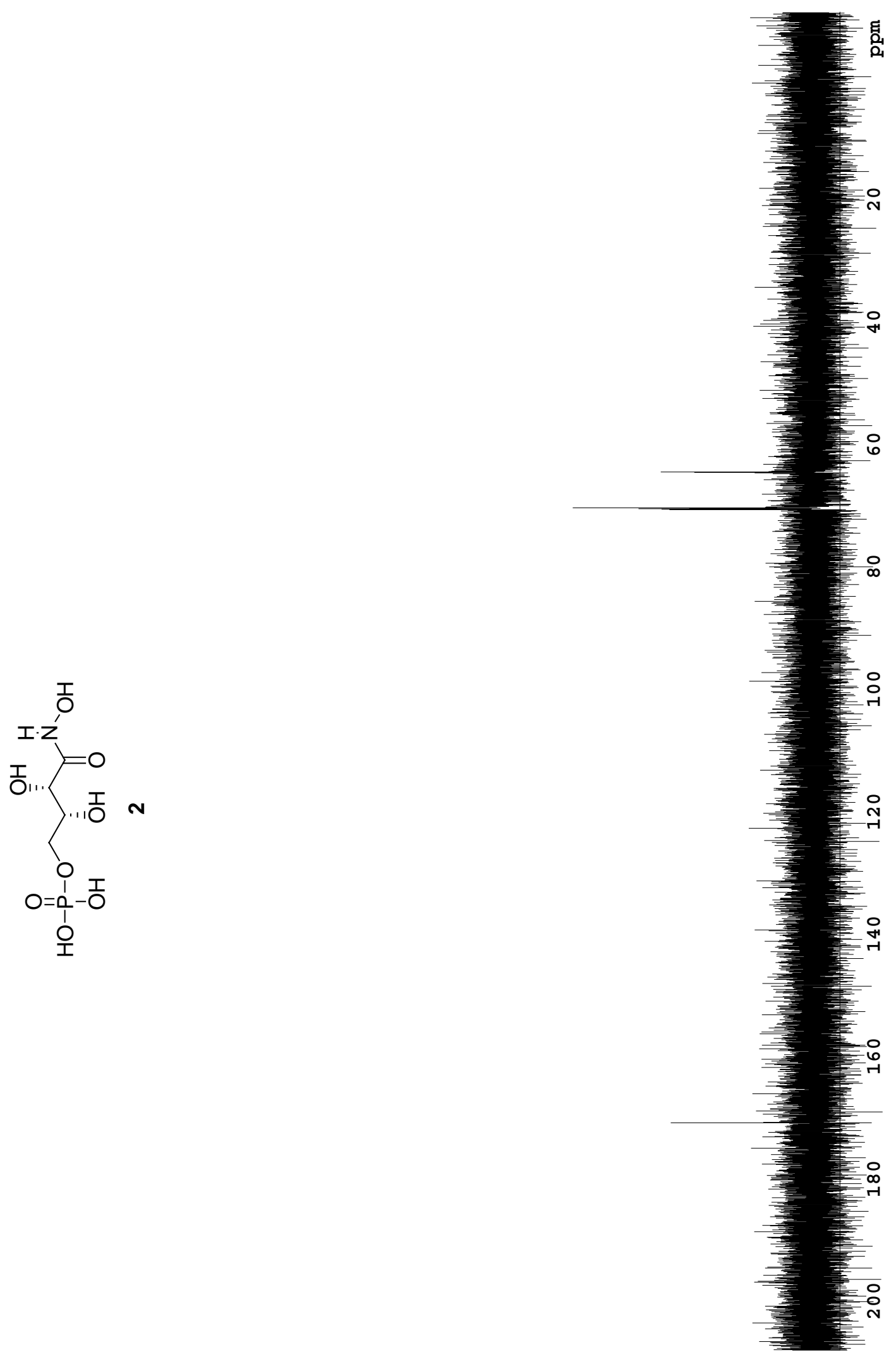

S19 

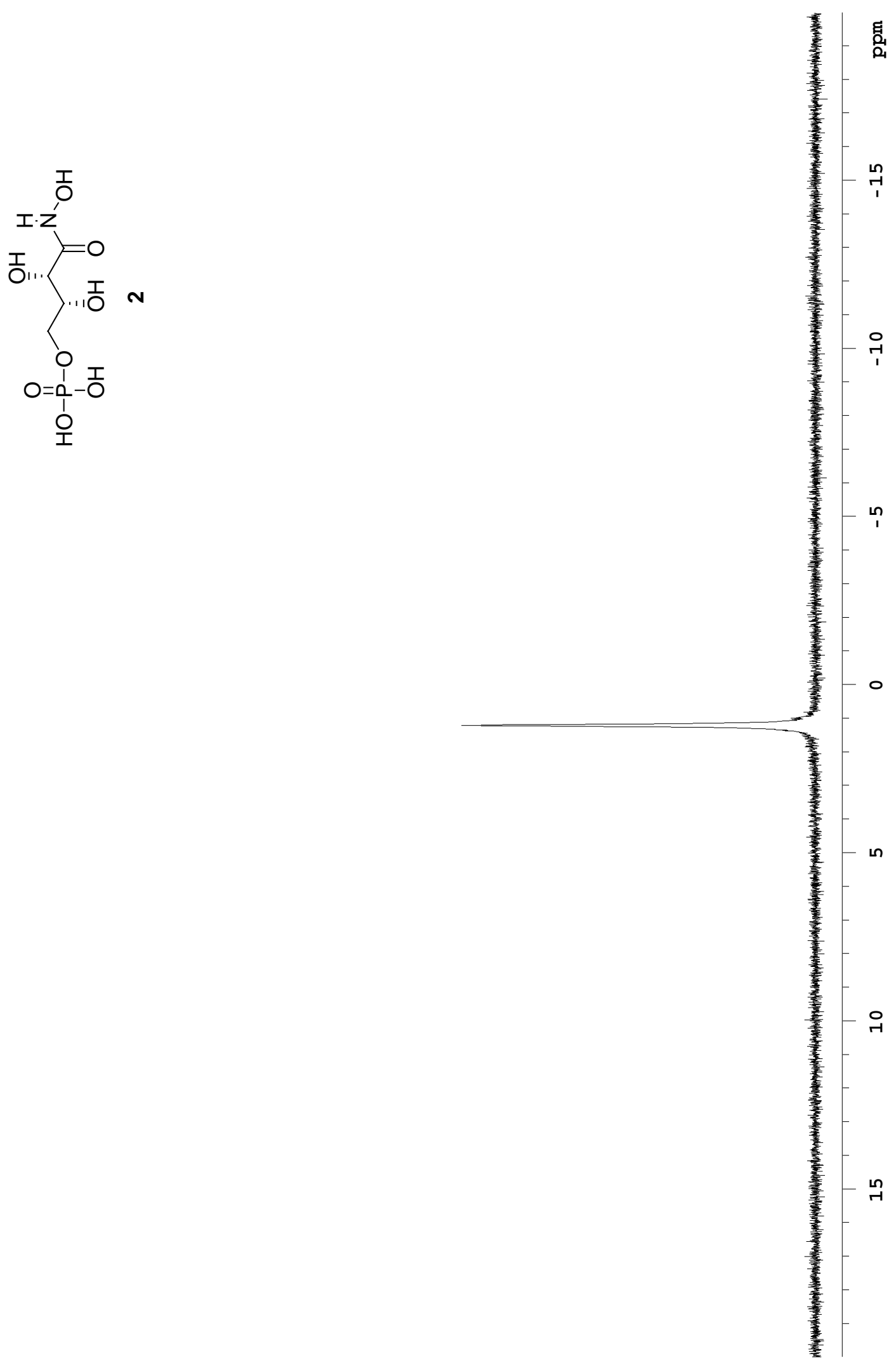


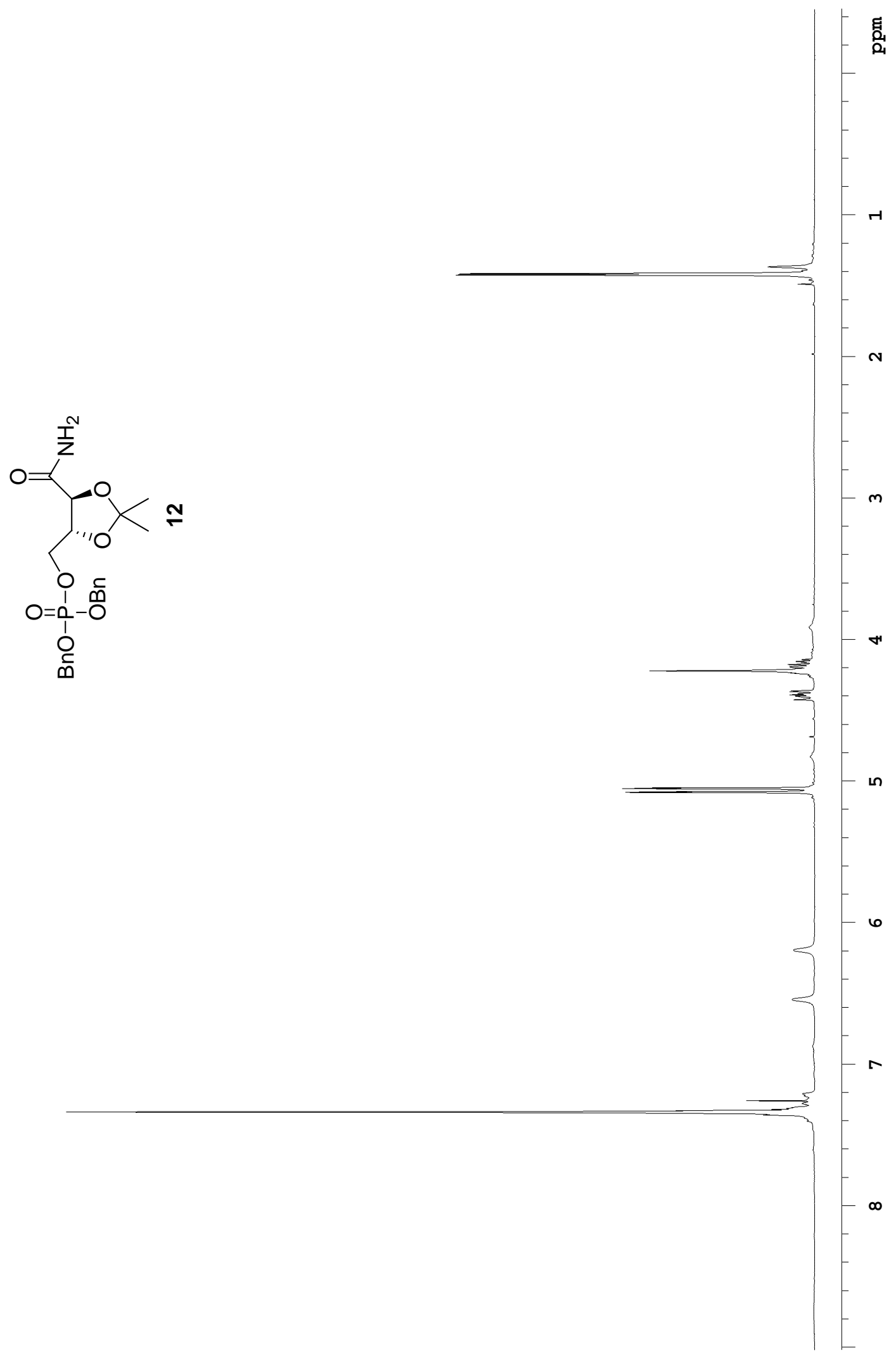




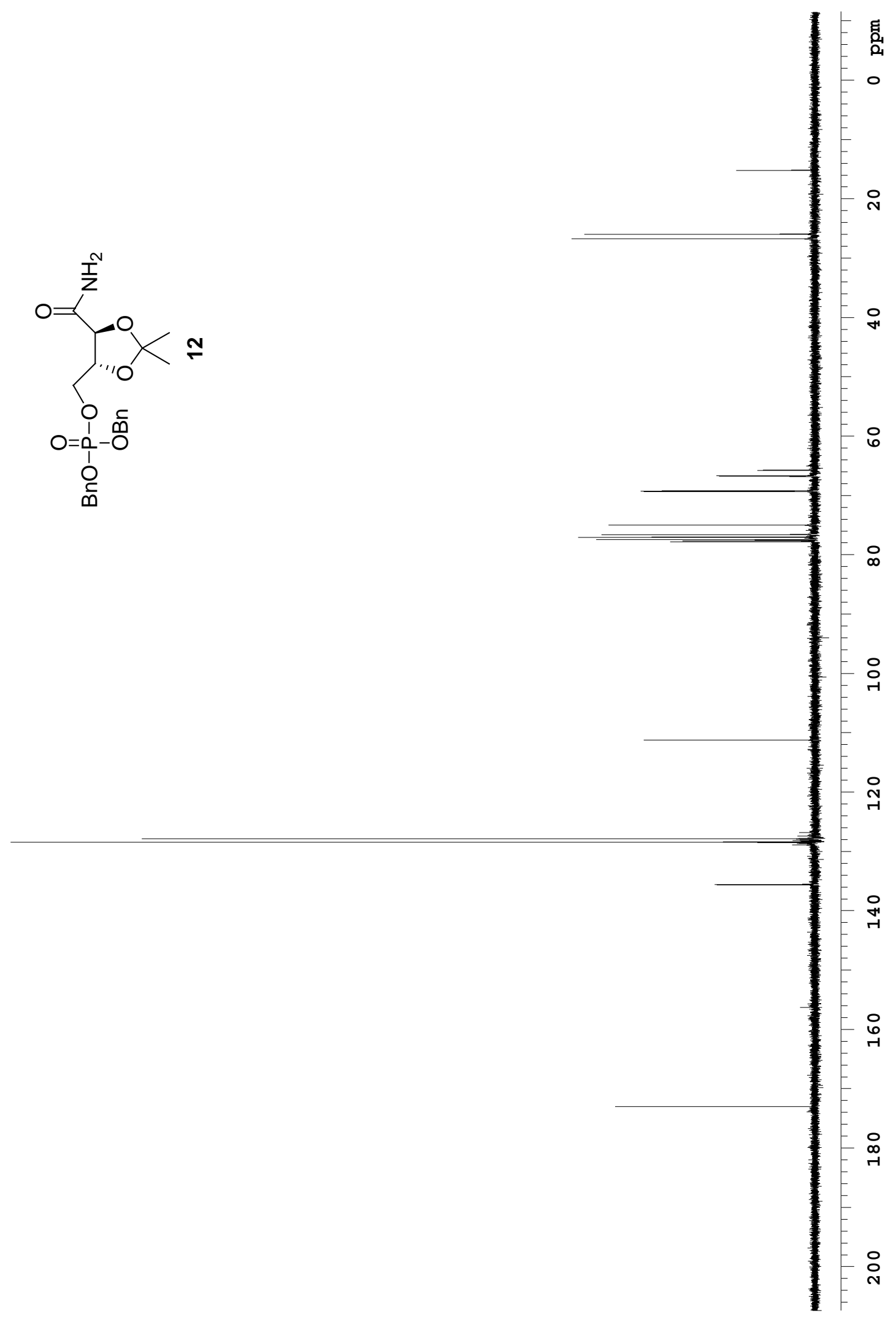




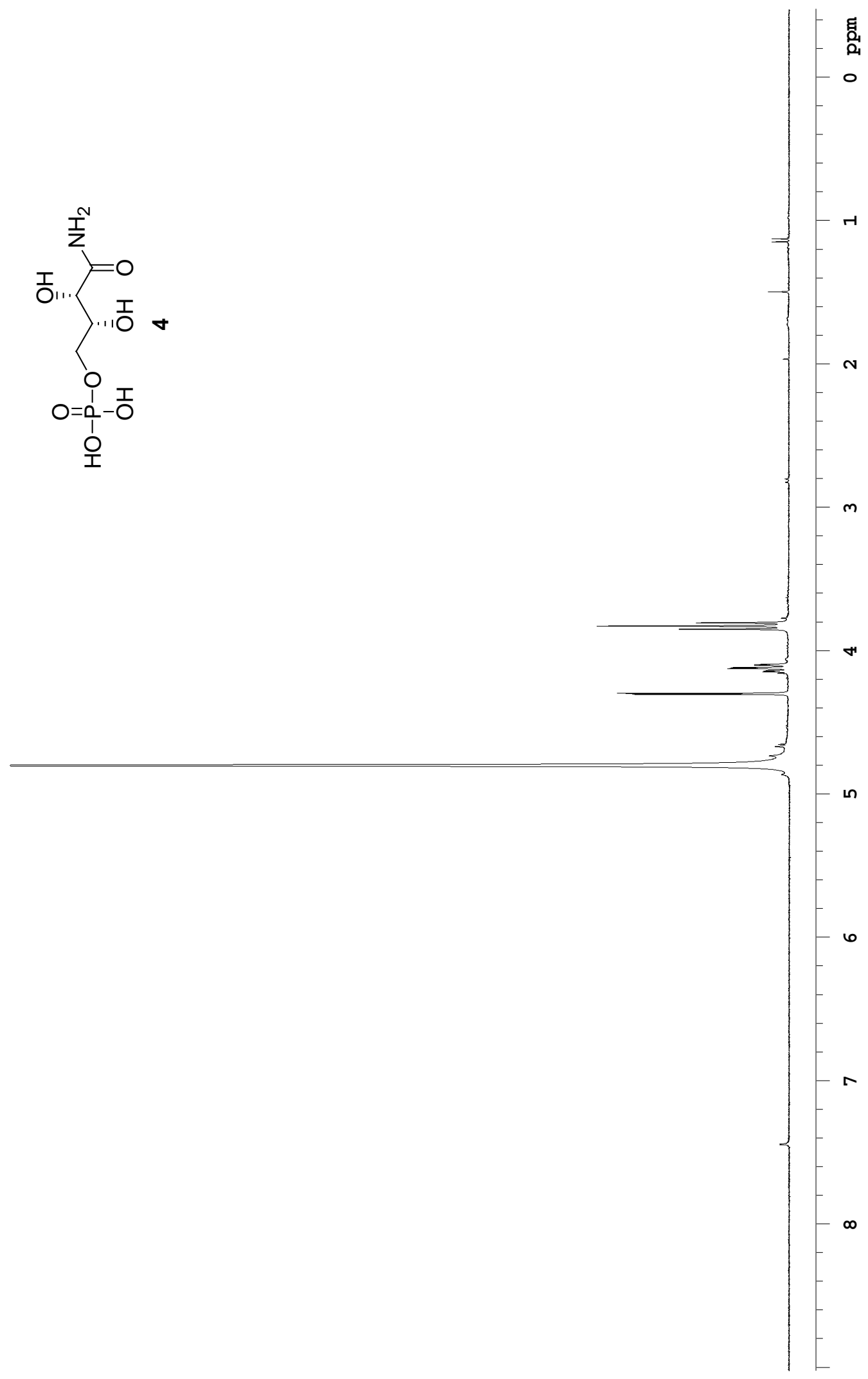




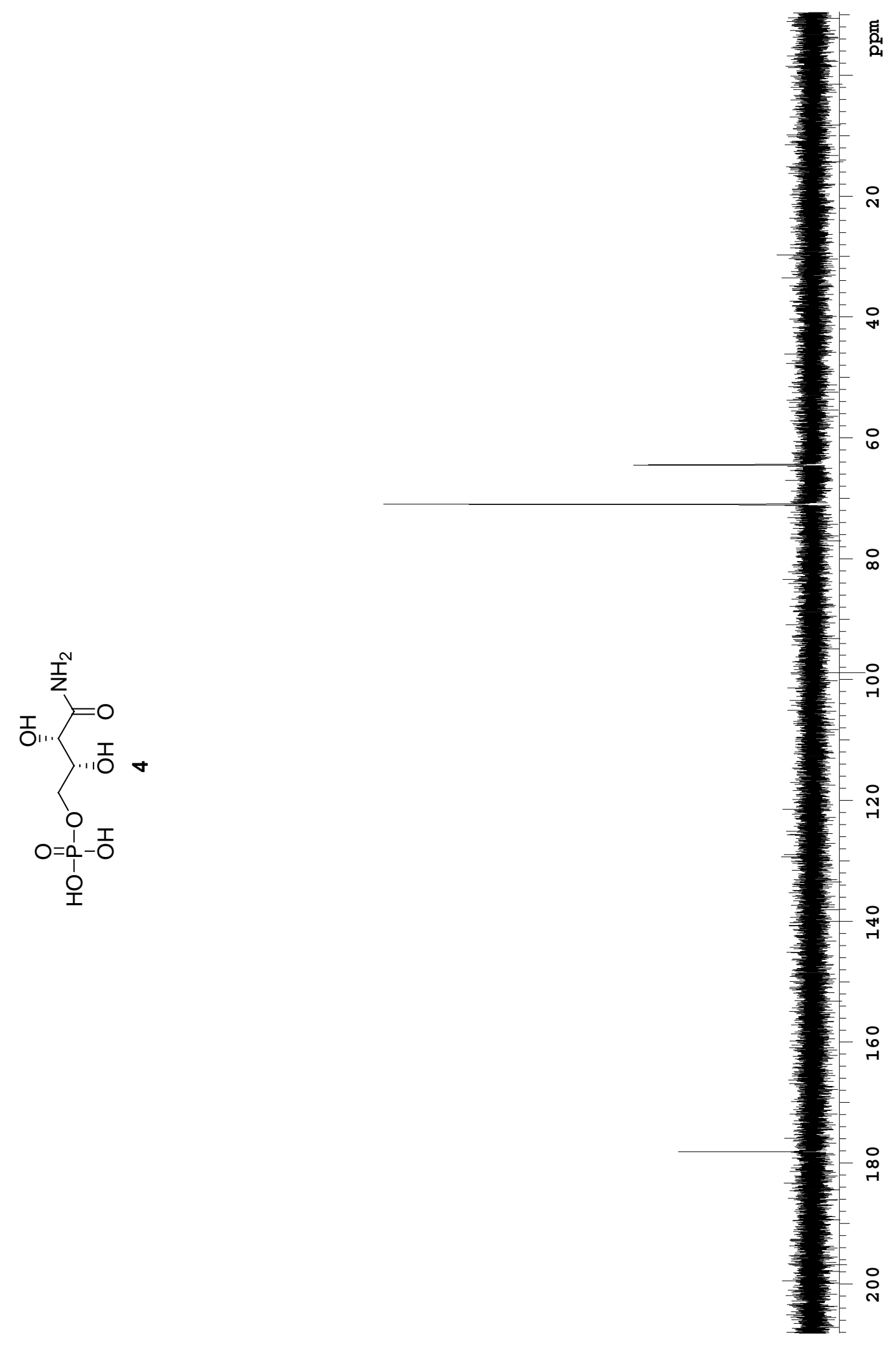



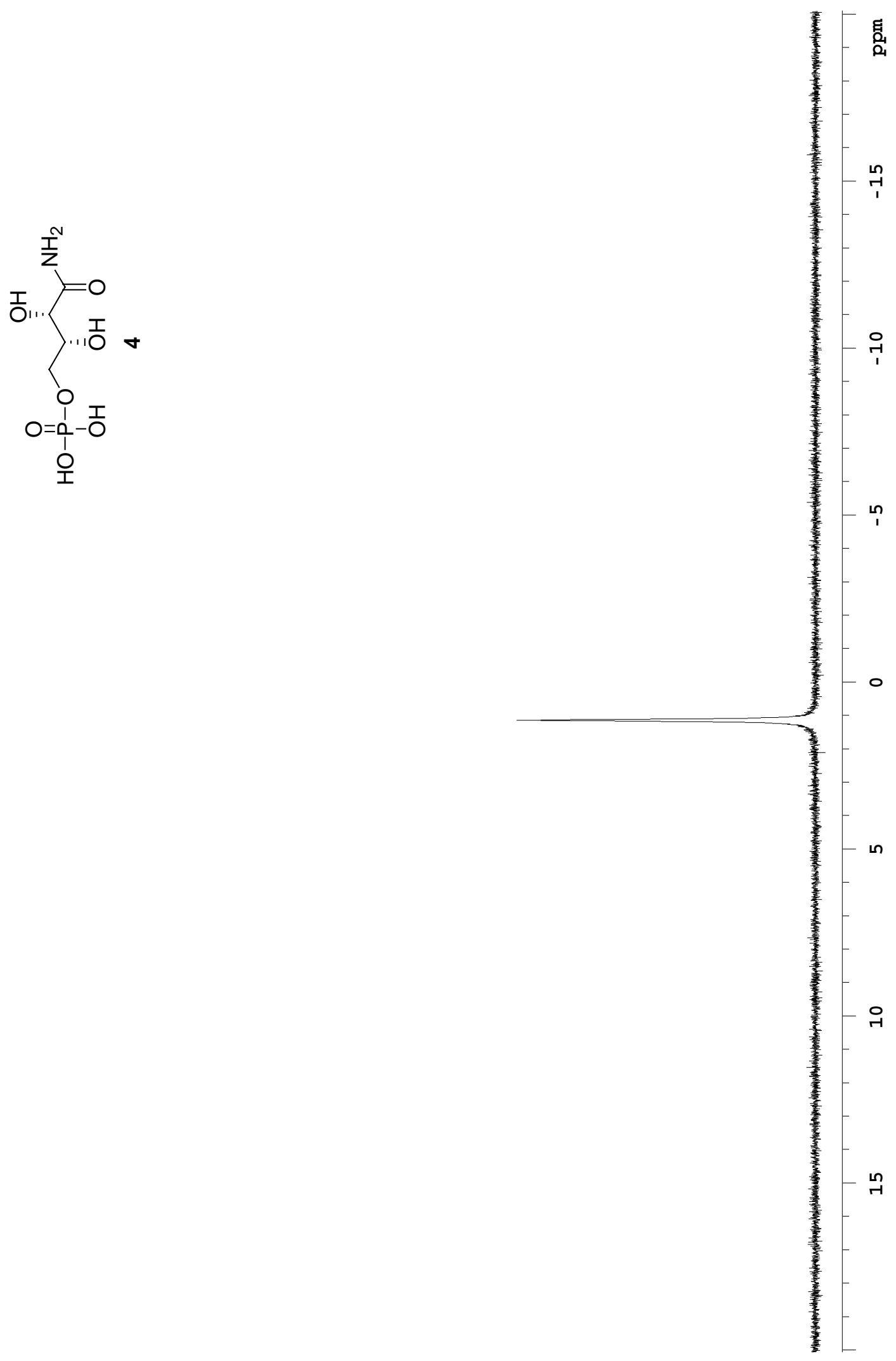


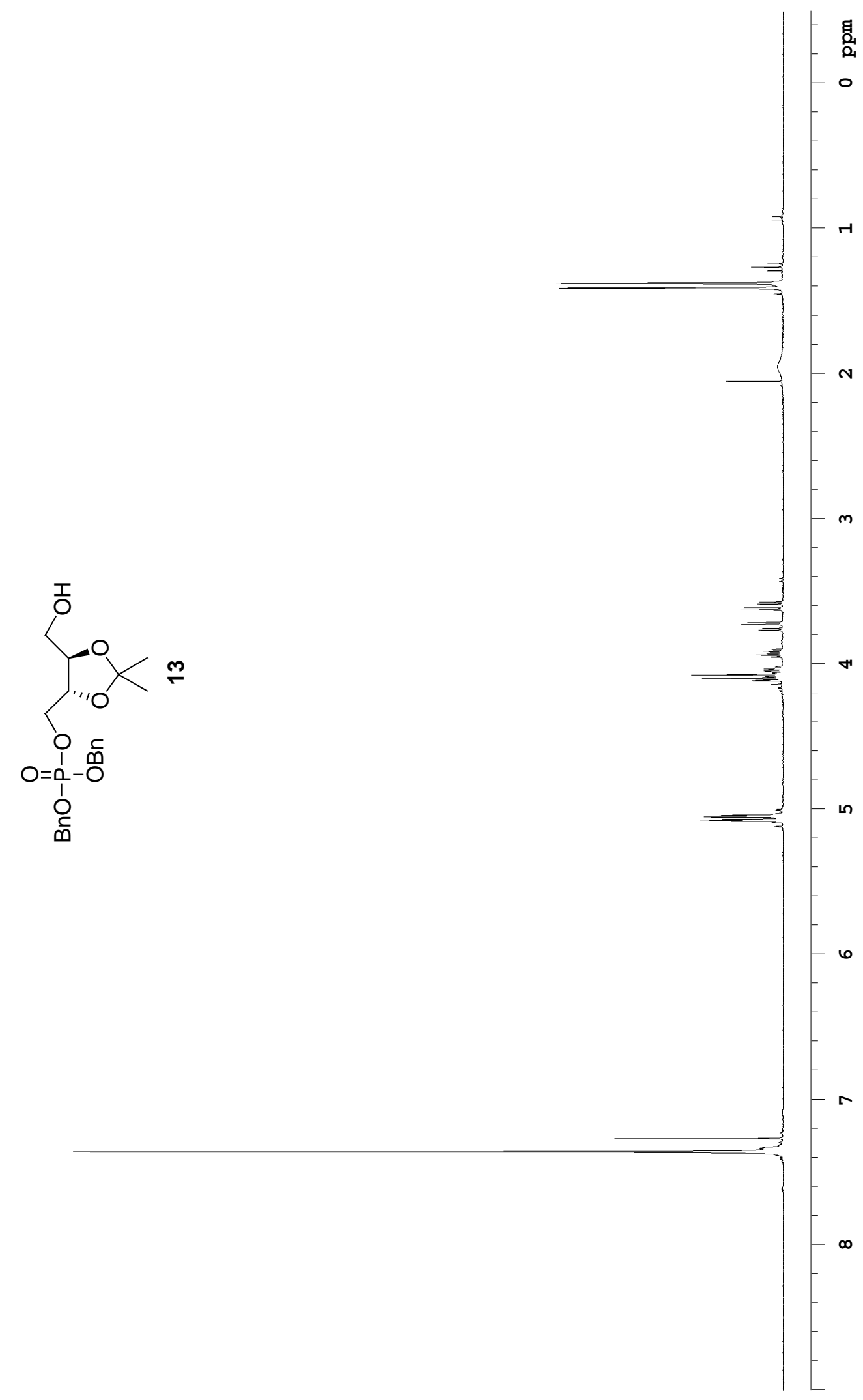



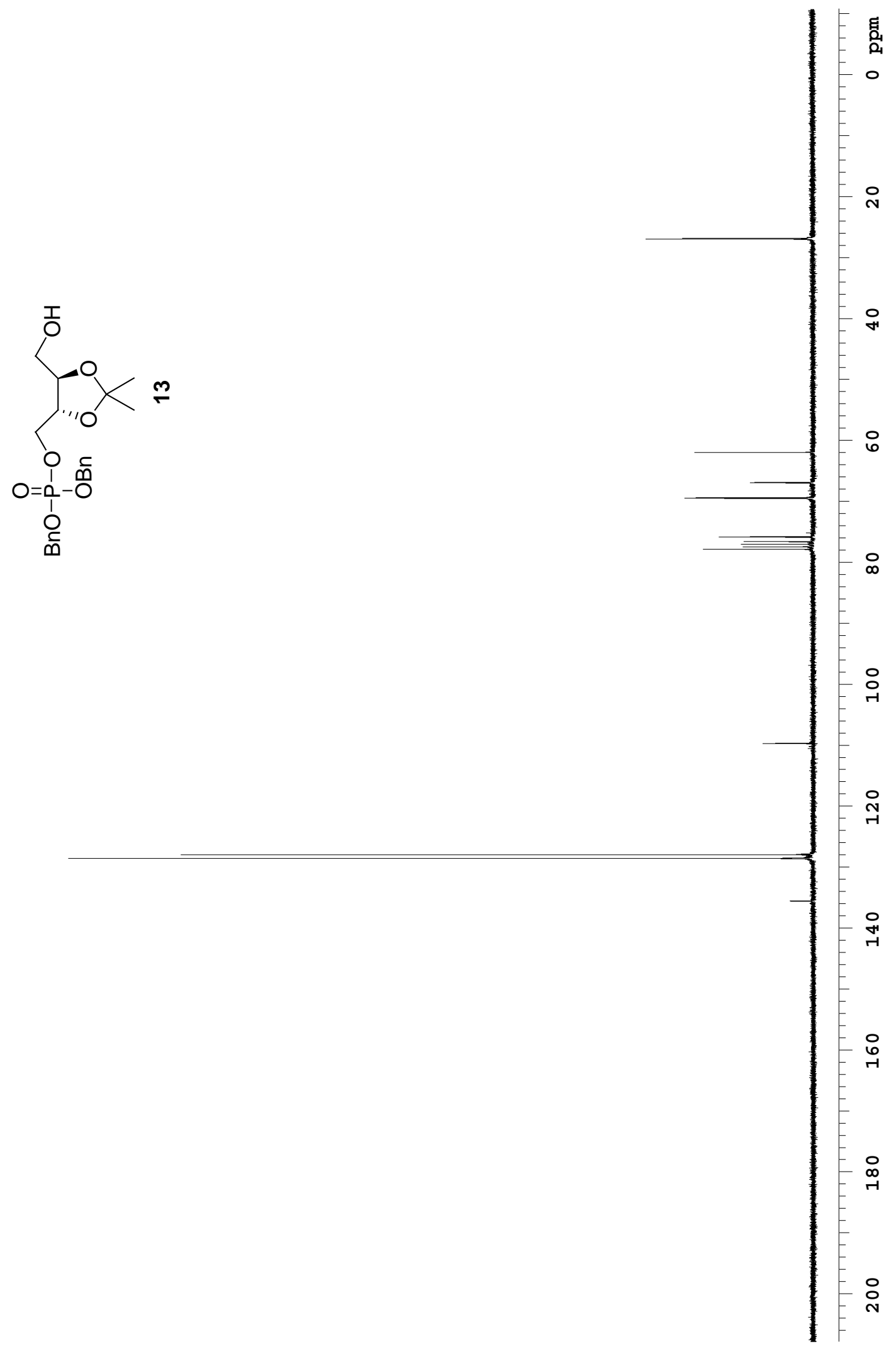

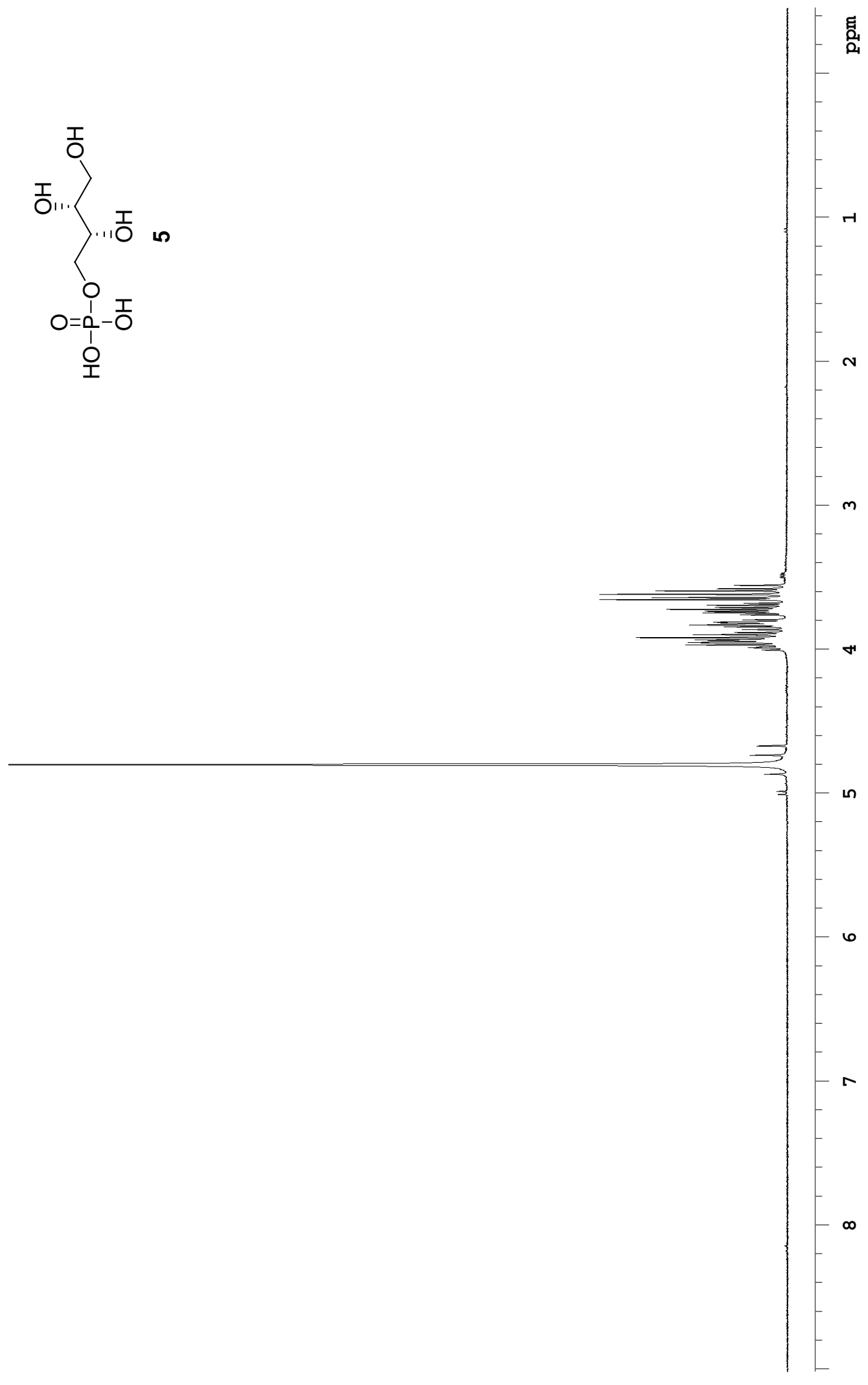

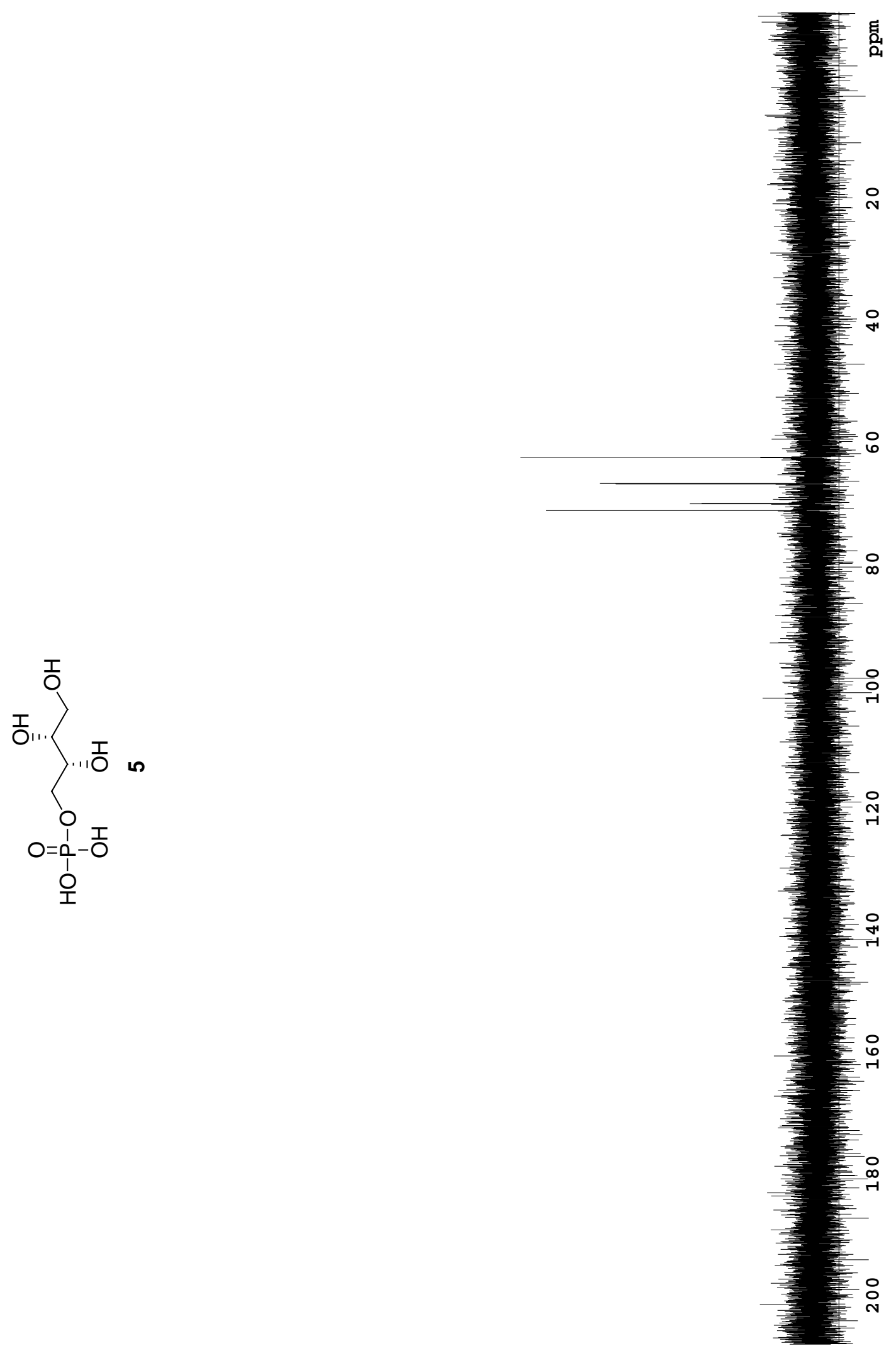

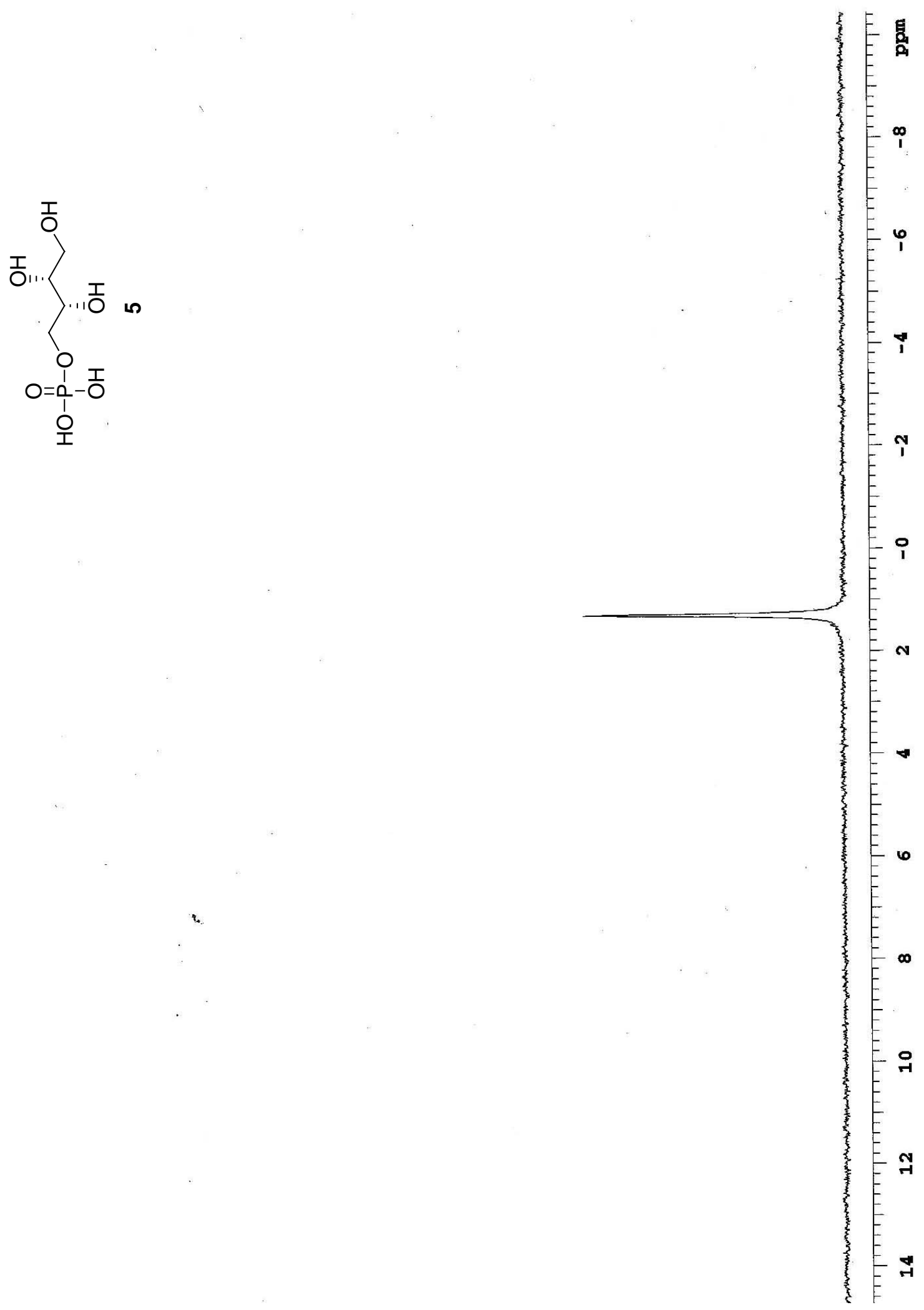


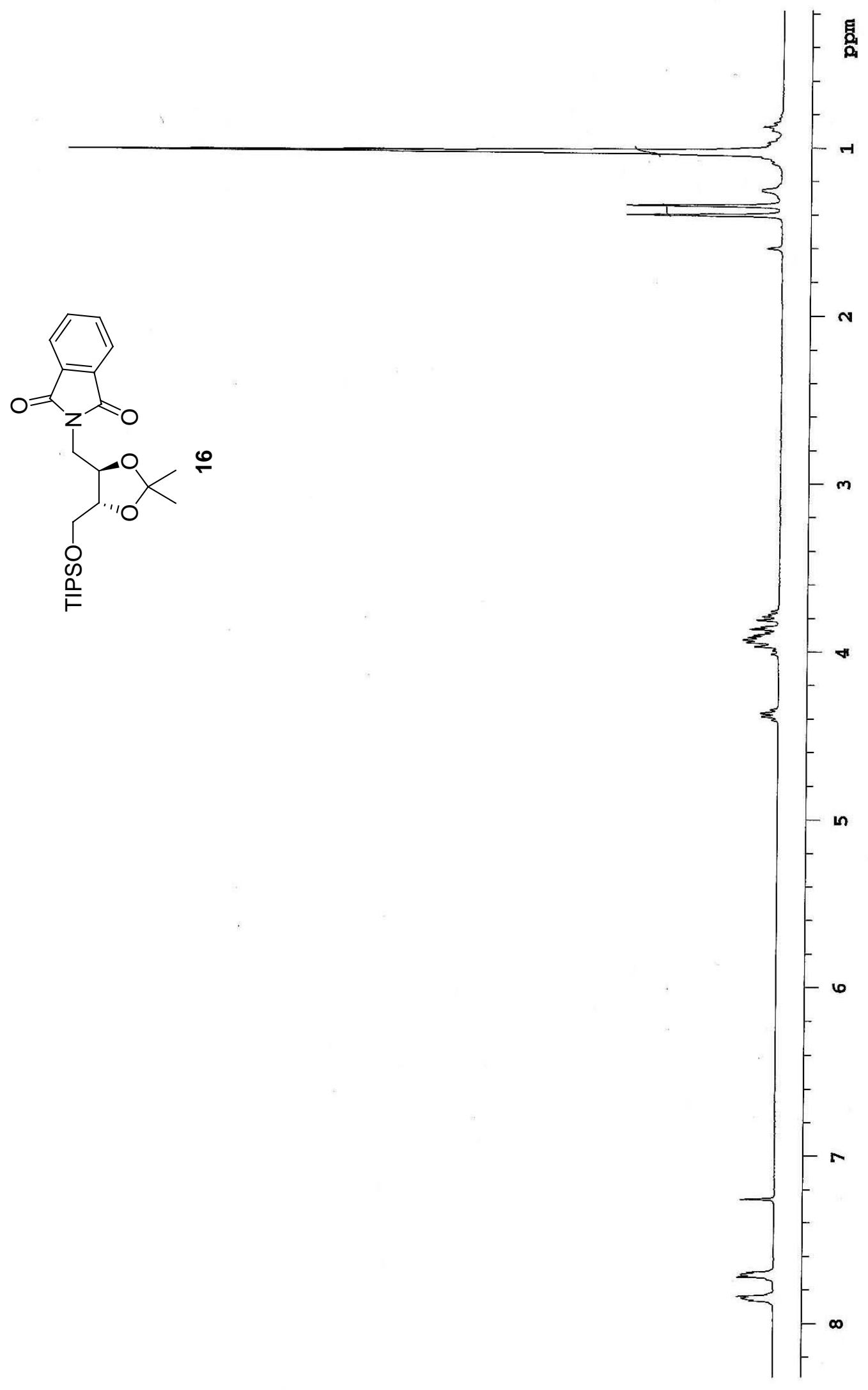




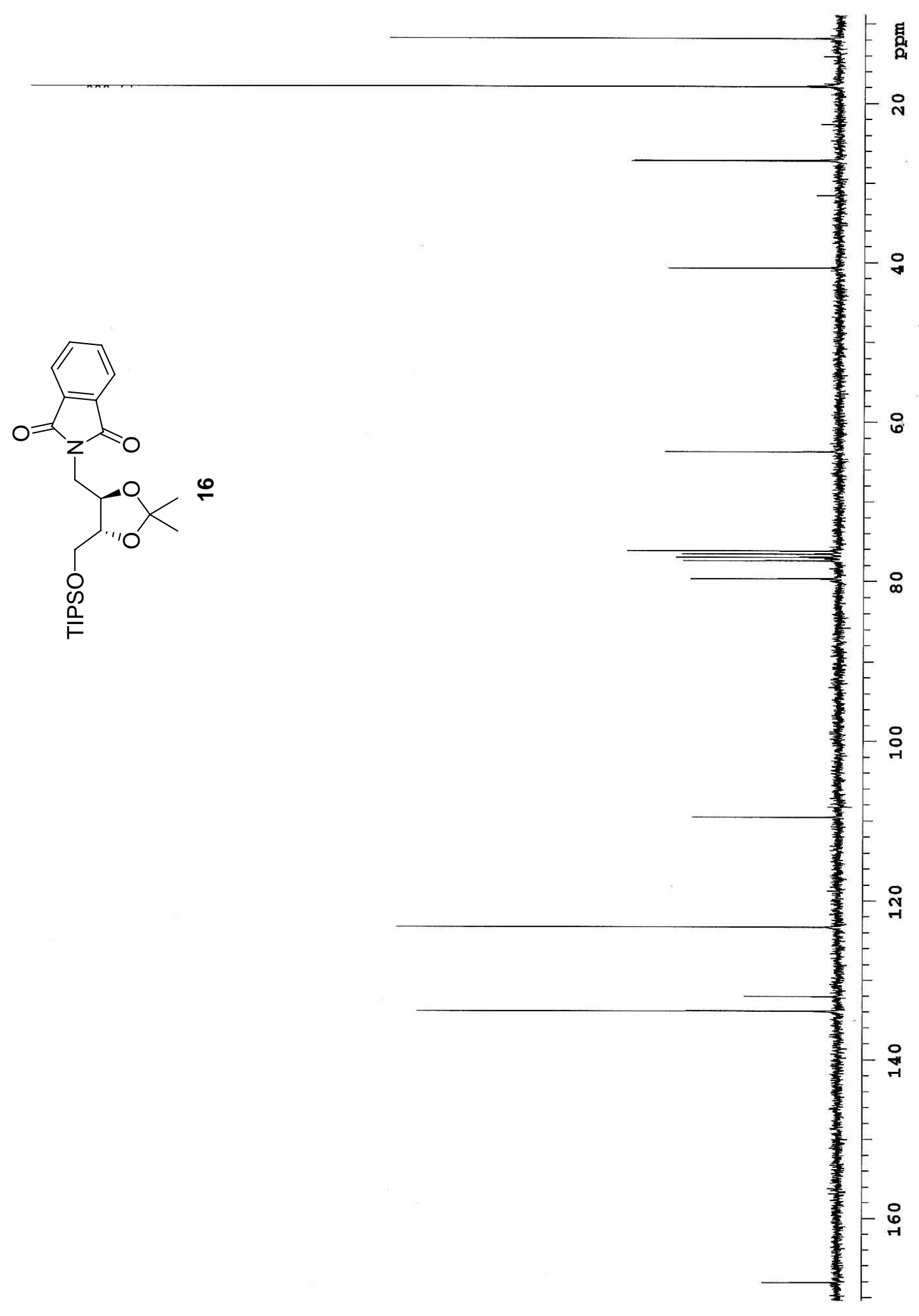




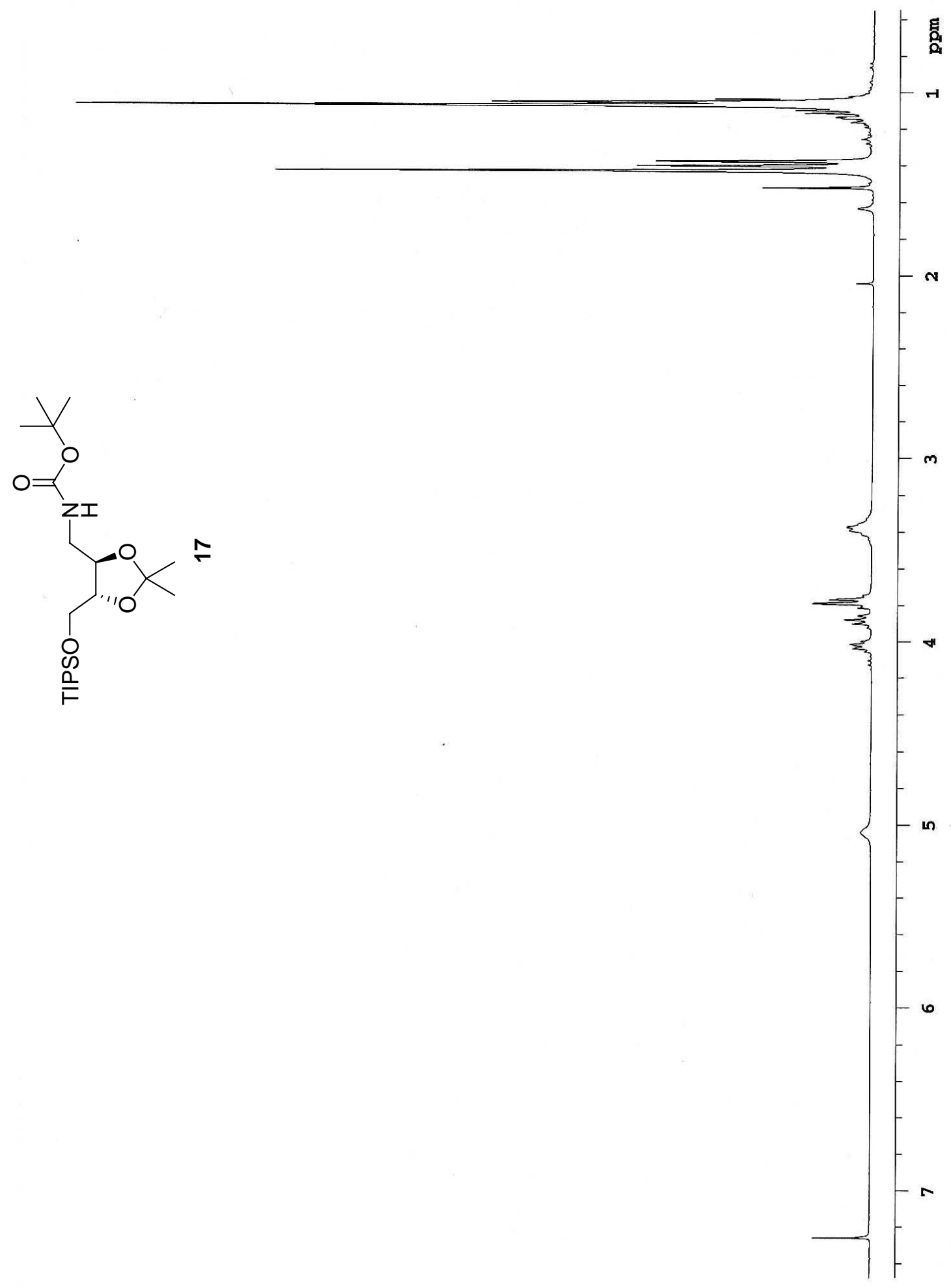




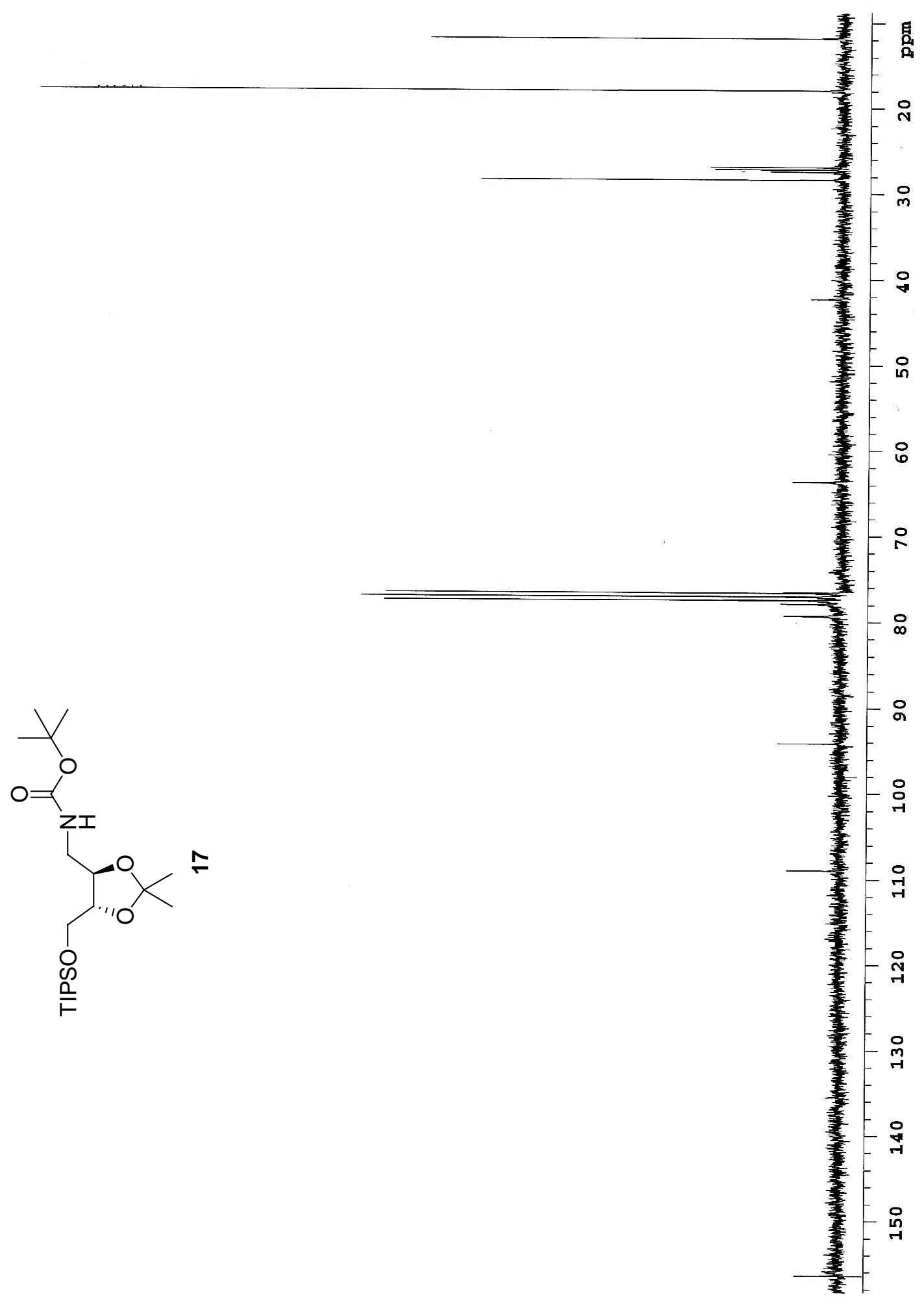




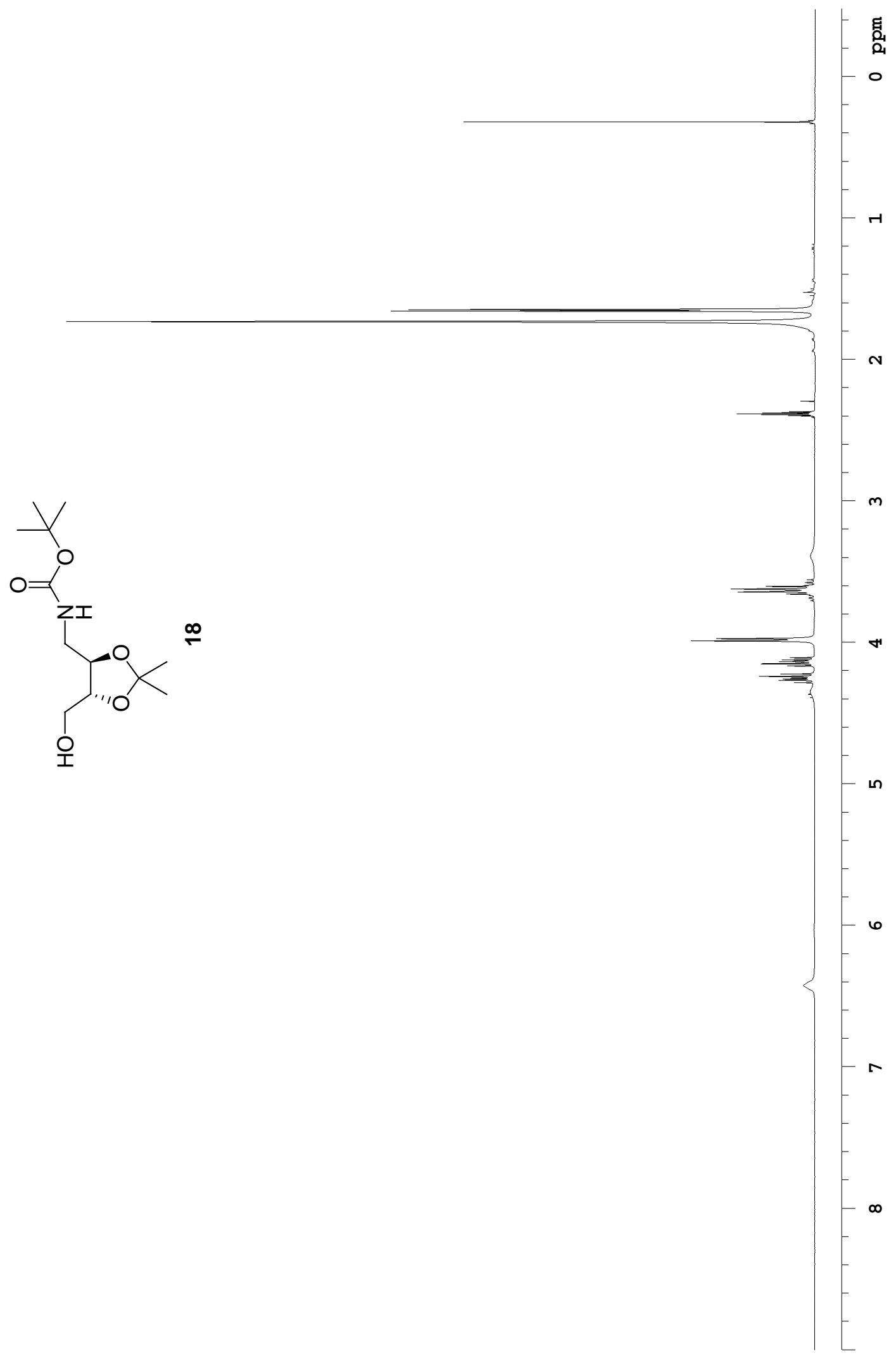




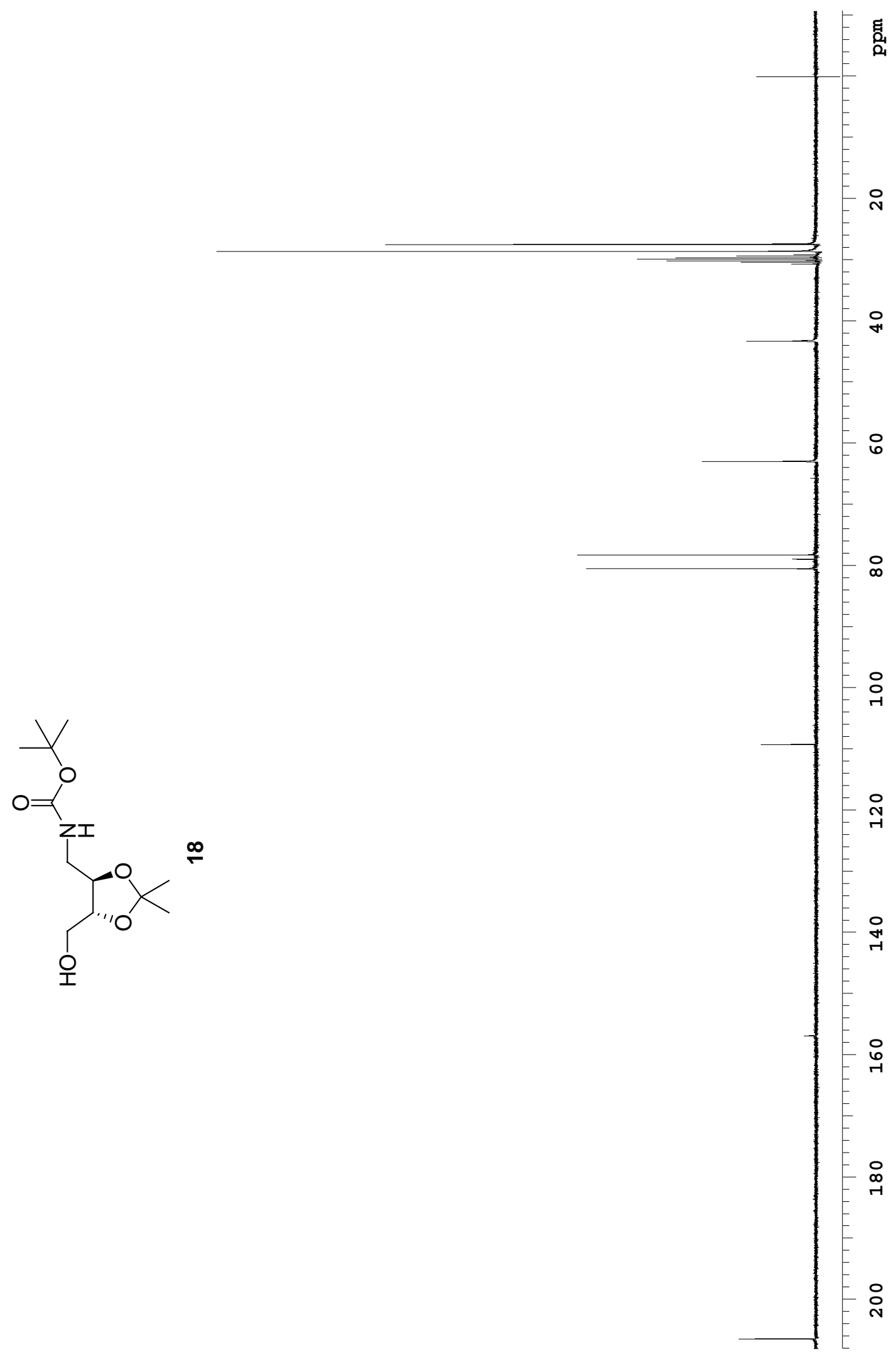




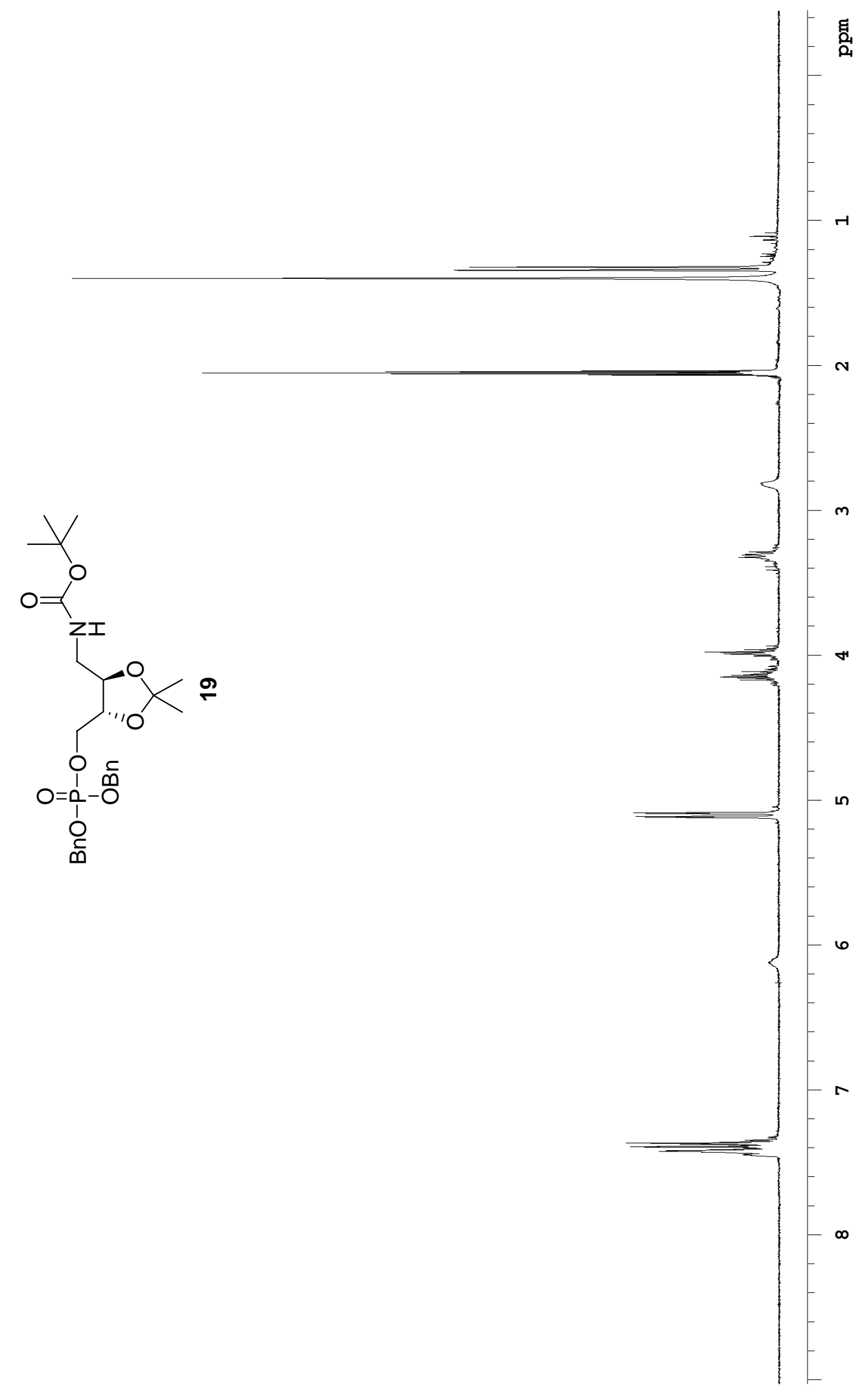



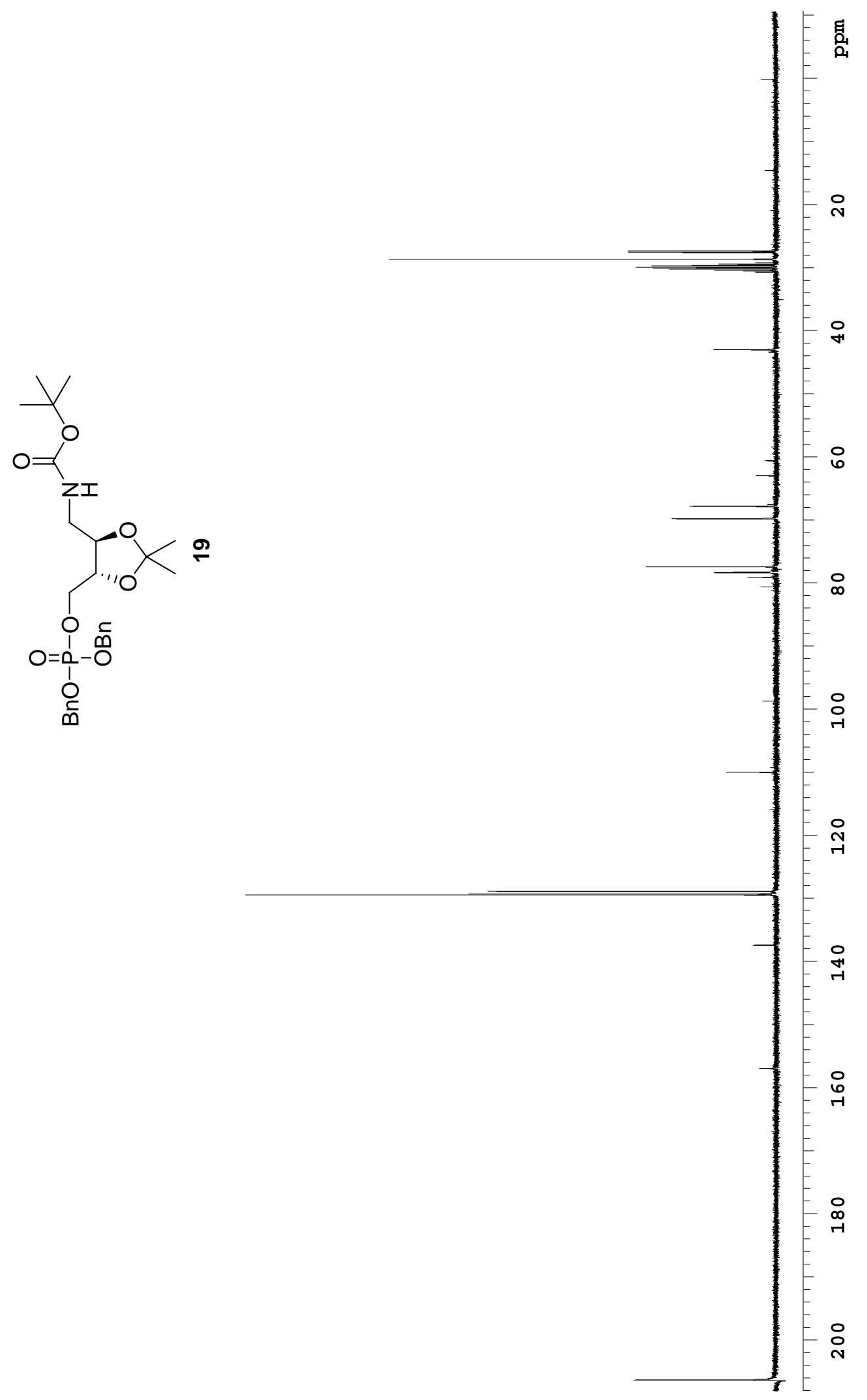


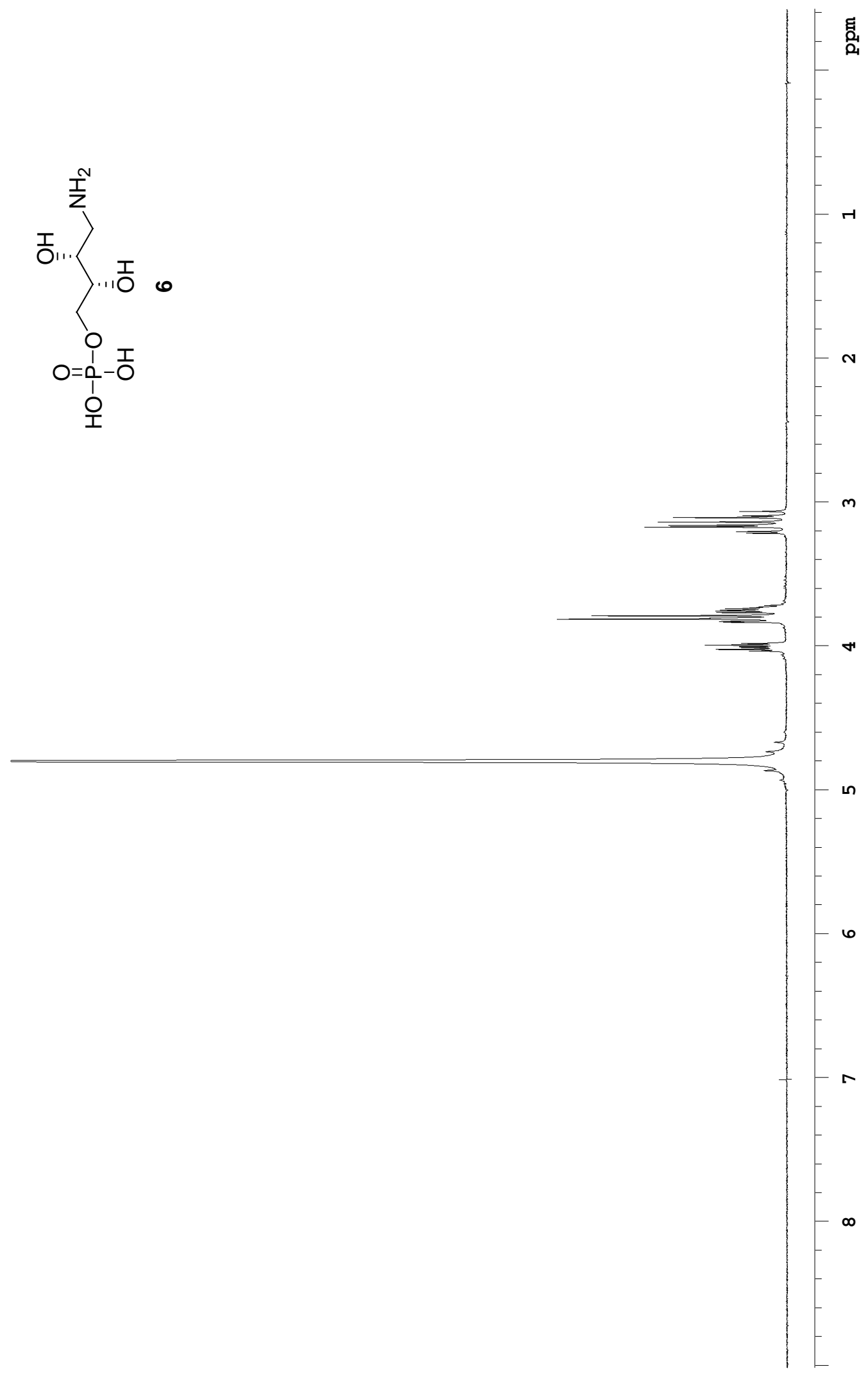




$$
1
$$



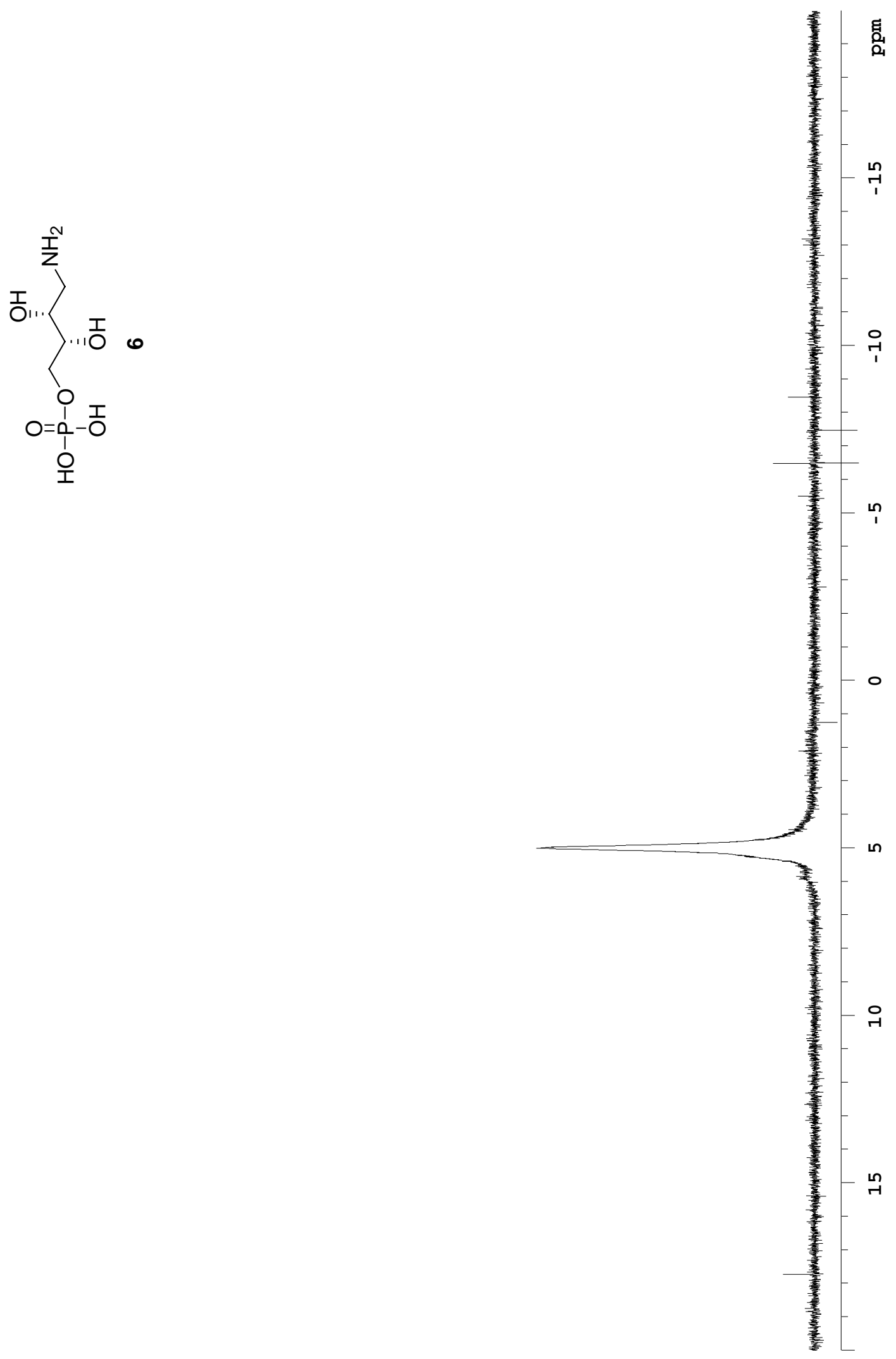